San Jose State University

SJSU ScholarWorks

Master's Theses

Master's Theses and Graduate Research

2003

\title{
Effects of lactation on blood glucose in Latina women with gestational diabetes
}

Manuel F. Villacorta

San Jose State University

Follow this and additional works at: https://scholarworks.sjsu.edu/etd_theses

\section{Recommended Citation}

Villacorta, Manuel F., "Effects of lactation on blood glucose in Latina women with gestational diabetes" (2003). Master's Theses. 2495.

DOI: https://doi.org/10.31979/etd.abuk-pyf9

https://scholarworks.sjsu.edu/etd_theses/2495

This Thesis is brought to you for free and open access by the Master's Theses and Graduate Research at SJSU ScholarWorks. It has been accepted for inclusion in Master's Theses by an authorized administrator of SJSU ScholarWorks. For more information, please contact scholarworks@sjsu.edu. 
EFFECTS OF LACTATION ON BLOOD GLUCOSE IN LATINA WOMEN WITH

GESTATIONAL DIABETES

\author{
A Thesis \\ Presented to \\ The Faculty of the Department \\ Of Nutrition and Food Science \\ San Jose State University \\ In Partial Fulfillment \\ Of the Requirements for the Degree \\ Master of Science
}

By

Manuel F. Villacorta

December 2003 
UMI Number: 1418724

\section{INFORMATION TO USERS}

The quality of this reproduction is dependent upon the quality of the copy submitted. Broken or indistinct print, colored or poor quality illustrations and photographs, print bleed-through, substandard margins, and improper alignment can adversely affect reproduction.

In the unlikely event that the author did not send a complete manuscript and there are missing pages, these will be noted. Also, if unauthorized copyright material had to be removed, a note will indicate the deletion.

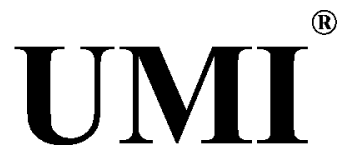

UMI Microform 1418724

Copyright 2004 by ProQuest Information and Learning Company.

All rights reserved. This microform edition is protected against unauthorized copying under Title 17, United States Code.

ProQuest Information and Learning Company 300 North Zeeb Road

P.O. Box 1346

Ann Arbor, MI 48106-1346 
(C) 2003

Manuel Fernando Villacorta

ALL RIGHTS RESERVED 
APPROVED FOR THE DEPARTMENT OF NUTRITION AND FOOD SCIENCE

Carr hllarkele

Clarice B. Hollenbeck, PhD Thesis Advisor

lug heptad

Lucy McProud, PhD, RD

Department Chair

Yolanda Dx Luting

Yolanda M. Gutierrez, PhD, RD

Committee Member

APPROVED FOR THE UNIVERSITY

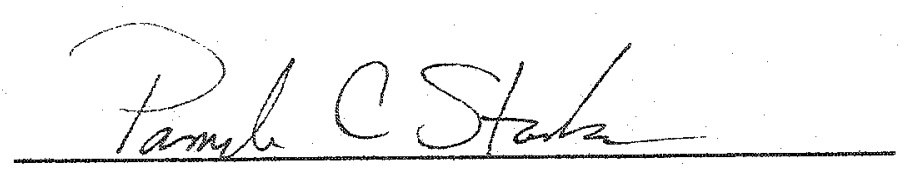




\begin{abstract}
Effects of Lactation on Blood Glucose in Latina Women with Gestational Diabetes By Manuel F. Villacorta

The present study examined the effects of breastfeeding on blood glucose regulation in Latina women with a history of gestational diabetes mellitus (GDM). Twenty Mexican-American women participated in the 3-month study. Blood glucose levels were measured five times per day, three days per week. Records of the number of times/day they breastfeed and 3-day maternal food records were completed on the same days they monitored their blood glucose levels. Maternal and infant weights were assessed at 6 weeks and 12 weeks postpartum. There were significant improvements in blood glucose both fasting and daylong in the women breastfeeding when compared to those feeding formula that could not be explained by differences in weight or calorie intake. These data support the notion that breastfeeding contributes to the improvement of blood glucose regulation in Latina women with GDM, and suggest that breastfeeding may provide protection in their progression toward type 2 diabetes.
\end{abstract}




\section{ACKNOWLEDGMENTS}

I sincerely thank my academic committee: Clarie Hollenbeck, Ph.D., Yolanda Gutierrez, Ph.D., MS, R.D., and Lucy McProud, Ph.D., R.D. Clarie, thank you for enlightening me and making this hard journey pleasurable with your knowledge and support. Yolanda, thank you for letting me work with you and your agency. Your encouraging enthusiasm and knowledge helped me on many occasions to keep going in order to fulfill my journey. Lucy, thank you for your editorial help in writing my thesis and the monetary awards received from the Nutrition and Food Science Department that helped fulfill my study. I feel proud to have three excellent professors on my committee making the impossible possible.

I thank my father in heaven and mother for giving me a strong foundation, supporting and teaching me the value of education.

I thank my partner Jeff for listening, encouraging, and supporting me through this very important moment in my life. Also, special thanks to my friend Jerry for helping me become a better computer and software user through this experience. 


\section{PREFACE}

The following is a publication style thesis. Chapters I and III are written according to the guidelines outlined in the Publication Manual of the American Psychological Association, $5^{\text {th }}$ edition, 2001. Chapter II is written in joumal format and will be submitted to Diabetes Care. 


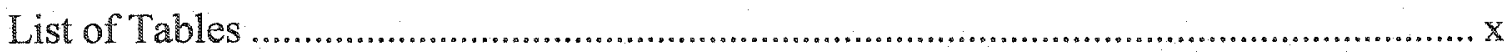

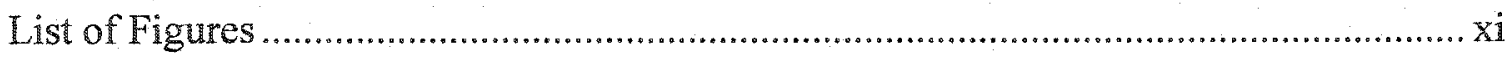

CHAPTER I: Introduction and Review of the Literature ...................................... 1

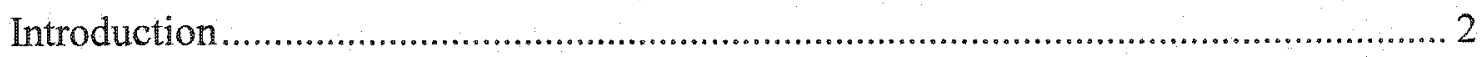

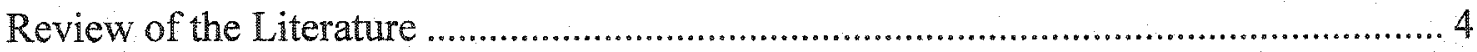

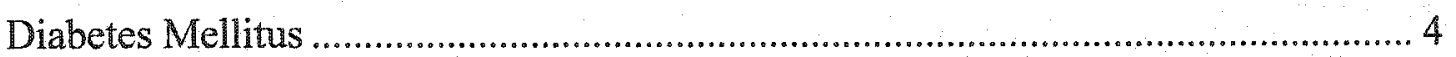

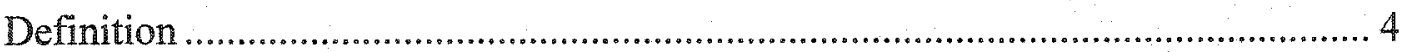

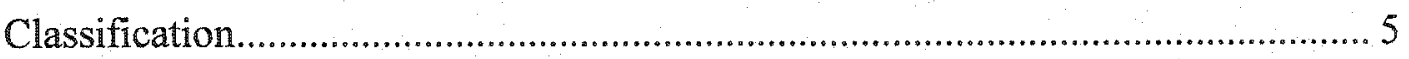

Type 1 Diabetes Mellitus .............................................................................. 5

Type 2 Diabetes Mellitus ...................................................................... 5

Gestational Diabetes Mellitus .................................................................. 6

Other Specific Types of Diabetes ....................................................... 6

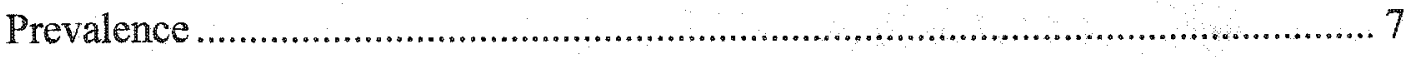

Gestational Diabetes Mellitus ........................................................................ 8

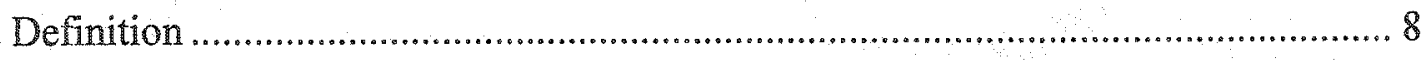

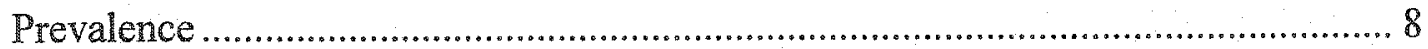

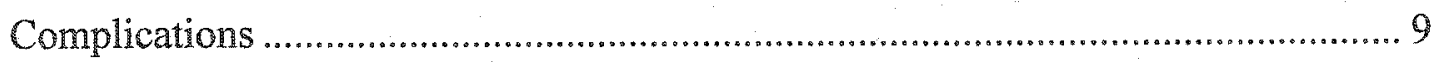

Prevention of Type 2 Diabetes in Women with Gestational Diabetes....................... 10

Weight Gain and Obesity ................................................................... 10

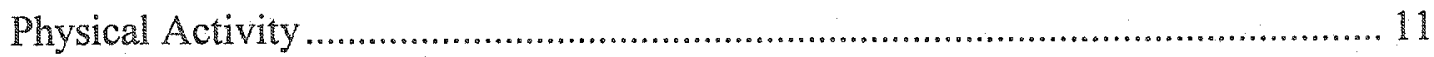




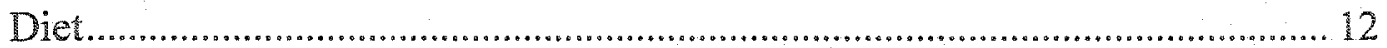

Subsequent Pregnancies.................................................13

Breastfeeding.......................................................... 13

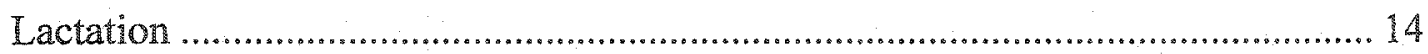

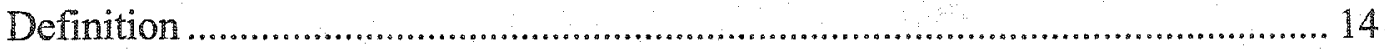

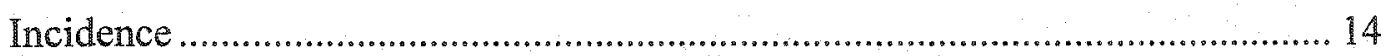

Energy and Macronutrients Requirements During Lactation ............................... 14

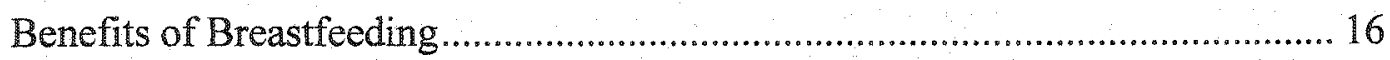

Breastfeeding and Diabetes Mellitus ...................................................................... 16

Breastfeeding and Type 1 Diabetes in Children ................................................. 16

Breastfeeding and Type 2 Diabetes in Children ................................................ 17

Beneficial Effect on Glucose Metabolism .......................................................... 17

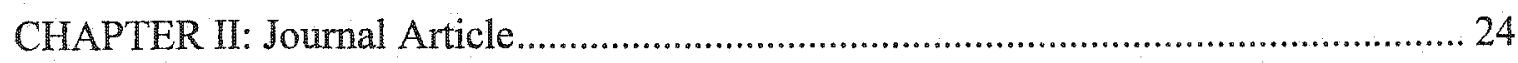

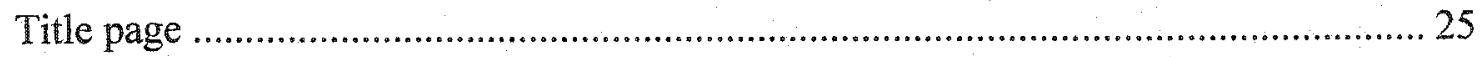

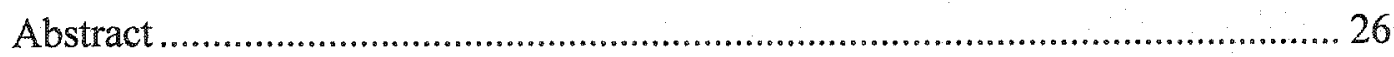

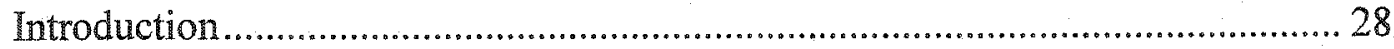

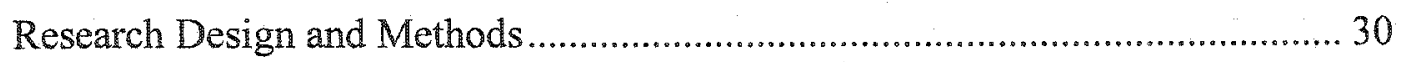

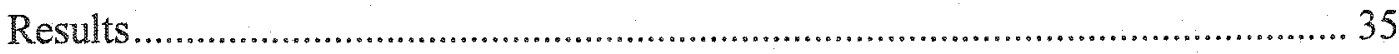

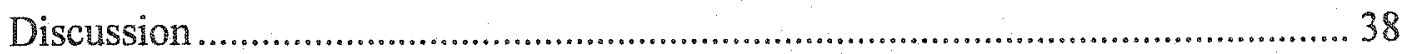

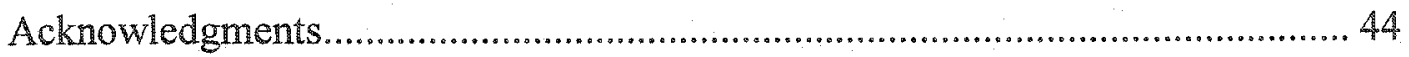

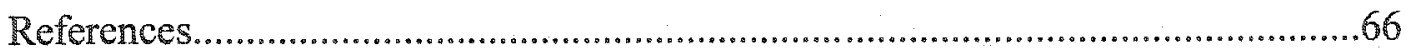

CHAPTER III: Summary and Recommendations ......................................................... 71 
Summary and Recommendations ......................................................................... 72

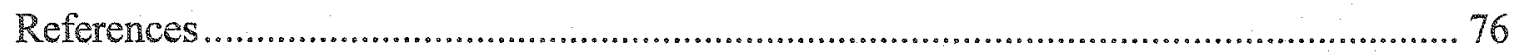

Appendix A Collaborative Letter................................................................................ 86

Appendix B Certification of Human Subjects Approval: Stanford University ..............87

Appendix C Institutional Review Board Approval: San Jose State University ............... 88

Appendix D Small Research Grant Award Letter ...........................................................8 89

Appendix E Circle of Friends Award Letter .................................................................... 90

Appendix F Informed Consent: English ……............................................................ 91

Appendix G Informed Consent: Spanish .................................................................... 94

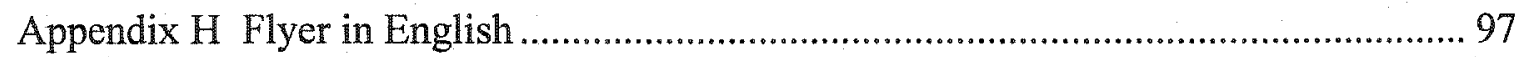

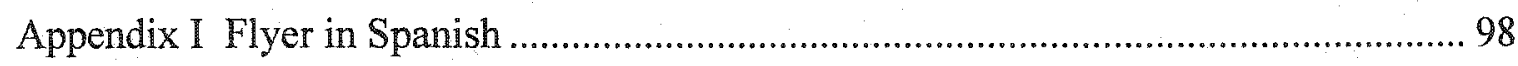

Appendix J Data Collection Tools: English .................................................................. 99

Appendix K Data Collection Tools: Spanish............................................................. 102 


\section{CHAPTER I}

Table

1. Health Benefits of Breastfeeding to the Infant and to the Mother.

\section{CHAPTER II}

Table

1. Clinical Characteristics of Overweight and Obese Latina Women with a History of Gestational Diabetes Mellitus ........................................................46

2. Fasting Blood Glucose in the Breastfeeding (BF) and Formula Feeding (FF) Groups by Week.

3. Ambient Blood Glucose (AMBG) in the Breastfeeding (BF) and Formula Feeding (FF) Groups by Week

4. Kilocalories Intake................................................... 49

5. Protein Intake................................................................ 50

6. Carbohydrate Intake........................................................

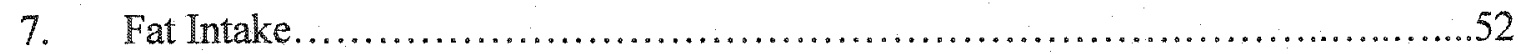

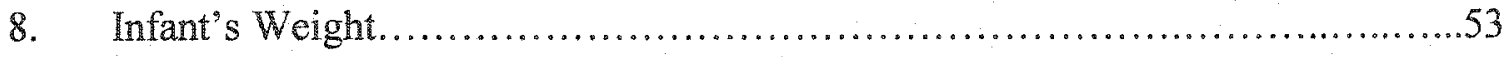

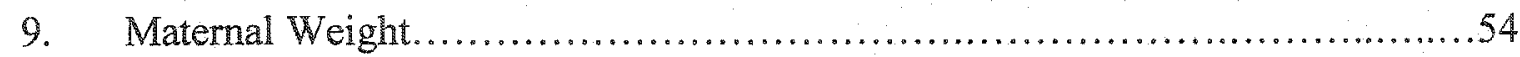

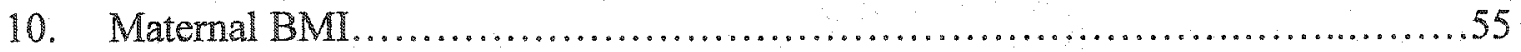




\section{List of Figures}

Figure

1. Capillary Plasma Blood Glucose Date of Delivery and Fasting Blood Glucose...56

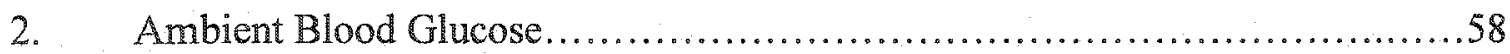

3. Breastfeeding Frequency by Week........................................60

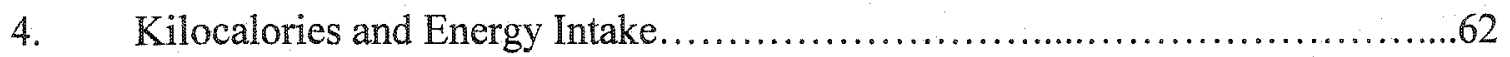

5. Macronutrient Distribution................................................64 
CHAPTER I

INTRODUCTION AND REVIEW OF THE LITERATURE 
Introduction

Diabetes Mellitus is a common disease. The estimated prevalence of diabetes among adults was $7.4 \%$ in 1995; this is expected to rise to $9 \%$ in 2025 (American Diabetes Association, 2003). The National Institutes of Health estimated that in 1998 a total of 15.7 million Americans were being affected by diabetes. Between 1980 and 1996 , the number of people diagnosed with diabetes increased by 2.7 million and in 1996 approximately 8.5 million people in the United States were diagnosed with diabetes. Diabetes was the seventh leading cause of death in the United States in 1996 (Central Disease Control and Prevention, Diabetes Program, 1999, statistics, chap.1).

In the United States, minority groups have substantially higher rates of diabetes than Caucasians (Anderson, J.W., 1998). In the Hispanic Health and Nutrition Examination Survey (Perez-Stable et al., 989) of 3,928 Mexican-Americans ages 20-74 years, the age-adjusted prevalence of self-reported diabetes was $6.8 \%$ among men and $7.6 \%$ among women. Comparable age-adjusted estimates for the U.S. population in a national survey were $2.9 \%$ in men and $3.8 \%$ in women (Perez-Stable et al., 1989).

The prevalence of diabetes in almost every age group is higher among women than men. Most of the Latina women with diabetes have type 2 diabetes and tend to be overweight (Lunt, 1996, Office on Women's Health, 1998, Diabetes Mellitus in Hispanic Women). Most of these women that developed type 2 diabetes had a history of gestational diabetes mellitus (GDM). Latina women who experienced GDM and postpartum impaired glucose tolerance have an $80 \%$ risk of developing type 2 diabetes within 5 years (Kjos et al. 1995). However, a woman who has had GDM can decrease 
the risk of developing type 2 diabetes by making several lifestyle changes. Studies have suggested that weight control, diet, and exercise can help decrease the development of type 2 diabetes in women with a history of gestational diabetes (Dornhost \& Rossi, 1998; Montenen, J., 2003; Tuomilehto et al. 2001). Breastfeeding may also play an important role in helping women with a history of GDM to decrease the risk of developing type 2 diabetes. Breastfeeding is associated with weight loss, which has been shown to reduce insulin resistance (Brewer, Meredith, Bates and Vannoy, 1989; Dewey, Heining \& Nommsen, 1993). Breastfeeding also requires more calories (Butte, Wong and Hopkinson, 2001; Institute of Medicine, 2002), and overweight and obese women who do not increase their calories while breastfeeding may benefit from weight reduction (Brewer, Meredith, Bates and Vannoy, 1989). For these reasons, lactation may have a beneficial effect on blood glucose metabolism; and by lowering blood glucose and for these reasons it is believed that breastfeeding may be protective for women in delaying the onset of type 2 diabetes (Ferris et al. 1988; Kjos et al., 1998; Kjos et. al., 2000; Kjos, Henry, Lee, Buchanan \& Mishell, 1993).

The purpose of the present study was to examine the effects of breastfeeding on day-long blood glucose regulation (fasting, 1 hour post-breakfast, lunch, dinner, and before bed time) during the first three months postpartum in Latina women with a history of GDM.

This observational exploratory study may be of potential significance to the medical community and to women with a history of GDM, as well as those at risk for developing GDM in the future. The present study will document the potential benefits of 
breastfeeding on blood glucose control in women who have experienced GDM.

Therefore, this study will provide health care professionals working with diabetes, insights into the aspects of breastfeeding promotion and success for the women who have had GDM; they may potentially benefit through return to pre-pregnancy weight sooner following delivery, improved blood control and reduced risk of developing type 2 diabetes. The results of the present study may add clarity to this important area of medicine. Most studies on lactation have focused on the quality and quantity of milk produced or on the effects of breast milk on infants. Relatively little attention has been given to the mother and her needs. Therefore, this study is critical because it will provide a profile of the effects of breastfeeding on normal daylong glucose regulation and the reestablishment of normal glucose regulation.

Review of the Literature

\section{Definition}

\section{Diabetes Mellitus}

Diabetes mellitus is a syndrome of metabolic abnormalities characterized by hyperglycemia (a state of elevated blood glucose) resulting from defects in insulin secretion, insulin action or both. All causes of diabetes ultimately lead to hyperglycemia which is the most common trait of this abnormality. People with chronic hyperglycemia are at risk of long-term damage, dysfunction, and failure of various organs, especially the eyes, kidneys, nerves, heart, and blood vessels (The Expert Committee on the Diagnosis and Classification of Diabetes Mellitus, 2003). 


\section{Classification}

Members of the Expert Committee on the Diagnosis and Classification of Diabetes Mellitus classify diabetes according to its etiology. Therefore, diabetes is divided into four distinct types, type 1 diabetes, type 2 diabetes, gestational diabetes mellitus (GDM) and other specific types (The Expert Committee on the Diagnosis and Classification of Diabetes Mellitus, 2003).

\section{Type 1 Diabetes Mellitus}

This form of diabetes results from a cellular-mediated autoimmune destruction of the $\beta$-cell in the Islets of Langerhans of the pancreas. Destruction of the $\beta$-cell usually leads to absolute insulin deficiency. The autoimmune destruction of $\beta$-cells has multiple genetic predispositions and is also related to environmental factors that are still poorly defined (The Expert Committee on the Diagnosis and Classification of Diabetes Mellitus, 2003). Type 1 diabetes was formally known as insulin dependent diabetes mellitus (IDDM) and was often thought of as juvenile onset diabetes.

\section{Type 2 Diabetes Mellitus}

Type 2 diabetes is a syndrome rather than a disease. It is characterized by insulin resistance with relative insulin deficiency (The Expert Committee on the Diagnosis and Classification of Diabetes Mellitus, 2003). It was formally known as noninsulin dependent diabetes mellitus (NIDDM), adult onset or obesity onset diabetes mellitus. There are many different etiologies of this form of diabetes and the etiology of this syndrome is not clearly defined. Most patients with type 2 diabetes are obese, or 
may have an increase in the \%age of body fat, with distribution predominantly in the abdominal region (The Expert Committee on the Diagnosis and Classification of Diabetes Mellitus, 2003). The risk of developing type 2 diabetes increases with age, obesity, and the lack of physical activity (American Diabetes Association, 2003). Type 2 diabetes is more common in individuals with a family history of diabetes and individuals of certain ethnic groups. It occurs more frequently in women with a history of gestational diabetes or polycystic ovary syndrome and is associated with hypertension, dyslipidemia, and impaired glucose tolerance (American Diabetes Association, 2003).

\section{Gestational Diabetes Mellitus}

GDM is defined as any degree of glucose intolerance associated with the onset of pregnancy (American Diabetes Association, 2003). GDM is described in greater detail later in this thesis.

\section{Other Specific Types of Diabetes}

Other forms of diabetes are characterized by genetic defects of the $\beta$-cell. Several forms of diabetes are associated with monogenetic defects in $\beta$-cell function. This form of diabetes is characterized by the onset of hyperglycemia at an early age, generally before the age of 25 years, and by impaired insulin secretion with minimal or no defects in insulin action. People inherit this form of diabetes in an autosomal dominant pattern (The Expert Committee on the Diagnosis and Classification of Diabetes Mellitus, 2003). 
Prevalence

Diabetes is a disease of high prevalence when compared with many other diseases. The exact prevalence is difficult to state because definitions and diagnostic criteria for diabetes have been evolving and differ in epidemiological studies (Gutteridge, 1999) and because it may be asymptomatic and not detected for many years. The estimated prevalence of diabetes among adults in 1995 was $7.4 \%$; this is expected to rise to $~ 9 \%$ by 2025 (American Diabetes Association, 2003). The National Institutes of Health estimated that in 1998 a total of 15.7 million Americans were affected with diabetes. Type 2 diabetes is the most prevalent form of diabetes, accounting for $90-95 \%$ of all diabetes. In addition, specific population subgroups have a much higher prevalence of diabetes than the population as a whole. Diabetes affects racial minorities and older people disproportionately. In 1998 of the 30 million Latinas, about 1.2 million have been diagnosed with diabetes and another 675,000 Latinas are believed to have diabetes, but remain undetected (Center for Disease Control and Prevention, 1999). In almost every group the prevalence of diabetes is higher among women than men. In the Hispanic Health and Nutrition Examination Survey of 3,928 Mexican-Americans ages 20-74 years, the age-adjusted prevalence of self-reported diabetes was $6.8 \%$ among men and $7.6 \%$ among women. Comparable age-adjusted estimates for the U.S. population in a national survey were $2.9 \%$ in men and $3.8 \%$ in women (Perez-Stable et al., 1989). Approximately 9.1 million or $8.9 \%$ of all women in the United States have diabetes and $25 \%$ of Latina women of all ages in the United States have been diagnosed with diabetes (Center for Disease Control and Prevention, 1999). For women who do not currently 
have diabetes, pregnancy brings the risk of gestational diabetes, especially for Latina women; $12 \%$ of Latina women develop type 2 diabetes after pregnancy. Both in California and nationwide, diabetes is the $5^{\text {th }}$ leading cause of death among Latinas, and the $4^{\text {th }}$ leading cause of death among Latina women (The Office on Women's Health U.S. Department of Health and Human Services, the National Women's Health Information Center, 2002).

\section{Definition}

\section{Gestational Diabetes Mellitus}

GDM is defined as any degree of glucose intolerance with onset or first recognition during pregnancy (American Dietetic Association, 2003). GDM is characterized by defects in both insulin action and insulin secretion, defects that are also common to type 2 diabetes (Ryan, O'Sullivan \& Skyler, 1985; Buchanan, Metzger, Freinkel \& Bergman, 1990). The definition applies whether insulin or diet modification is used for treatment and whether or not the condition persists after pregnancy (American Dietetic Association, 2003).

Prevalence

Approximately $7 \%$ of all pregnancies are complicated by GDM, resulting in more than 200,000 cases annually. The prevalence may range from 1 to $14 \%$ of all pregnancies, depending on the population studied and the diagnostic test employed (American Dietetic Association, 2003). Not all women diagnosed as having GDM in an index pregnancy have GDM in subsequent pregnancies. According to Moses (1996) the recurrence rate for GDM ranges from 30 to $50 \%$. However, the recurrence rate for GDM 
is highest among ethnic groups with high prevalence rates of type 2 diabetes (Philipson, 1989).

\section{Complications}

The predominant complication to women with gestational diabetes is an increased frequency of hypertensive disorders. Careful monitoring of blood pressure, weight gain, and urinary protein excretion is recommended (Kjos \& Buchanan, 1999). The dominant ante-partum clinical risks of gestational diabetes are to the fetus. Macrosomia, hypoglycemia, jaundice, respiratory distress syndrome, polycythemia, and hypocalcemia have been reported with varying frequency in the infants of women with gestational diabetes (Kjos \& Buchanan, 1999). Although most women with GDM revert to normal glucose tolerance postpartum, they are at increased risk of developing gestational diabetes in subsequence pregnancies (Moses, 1996). In addition, women with a history of GDM are at greater risk for the development of overt diabetes, particularly type 2 diabetes in the future. Studies show that the development of diabetes was nearly $50 \%$ after five years postpartum follow up in women who experienced GDM (Metzger \& Cho, 1993; Kjos et al., 1995).

\section{Prevention of Type 2 Diabetes in Women with Gestational Diabetes}

Women with a history of GDM are at an increased risk of developing diabetes in the future, predominantly type 2 diabetes (Metzger \& Cho, 1993; Kjos et al., 1995). There are several studies which suggest that the extent of the risk of future type 2 diabetes depends both on diagnostic criteria used to identify GDM (Metzger et al., 1985) and on matemal risk factors. Some of the matemal risk factors may be modifiable 
postpartum to prevent the development of type 2 diabetes. However, there are also factors that cannot be modified. The non-modifiable risk factors include ethnicity (Berkowitz, Lapinski, Wein \& Lee, 1991), pre-pregnancy weight (Metzger, Cho, Roston, Radvany, 1993), age, parity, family history of diabetes (Dornhorst et al., 1992), and degree of hyperglycemia in pregnancy and immediately after postpartum (Metzger \& Cho, 1993; Kjos et al., 1995; Henry \& Beischer, 1991). There is evidence that some women with a history of gestational diabetes show relative $\beta$-cell dysfunction both during and after pregnancy (Buchanan, Metzger, Freinkel \& Bergman, 1990; Dornhost et al., 1990; Metzger, Cho, Roston, Radvany, 1993). Most women with a history of GDM are insulin resistant, both during and after pregnancy (Pallardo, 1999; Ryan et al., 1995). To this extent, there are some lifestyle changes that may improve insulin sensitivity postpartum and theoretically preserve $\beta$-cell function and slow the progression of type 2 diabetes (Dornhorst \& Frost, 1997). The Diabetes Prevention Program Research Group (2002) concluded that type 2 diabetes can be prevented or delayed in persons at high risk for the disease, such as women with a history of GDM, by making life style changes. The modifiable risk factors are obesity, future weight gain, level of physical activity, subsequent pregnancies, and breastfeeding. Results from research suggest that life style changes may reduced the incidence of diabetes by $58 \%$ (Diabetes Prevention Program Research Group, 2002).

Weight Gain and Obesity

There is strong evidence that obesity, weight gain, and physical inactivity are the main modifiable determinants for the development of type 2 diabetes (Tuomilehto et al., 
2001). Epidemiological studies emphasize the fact that obesity is a major contributing factor for the development of type 2 diabetes in women (The Office on Women's Health U.S. Department of Health and Human Services, the National Women's Health Information Center, 2002). Women who lose weight to reach and maintain their ideal body weight decrease the risk significantly and studies suggest that diabetes could be delayed or prevented with only modest changes in weight (Dornhorst \& Rossi, 1998; Tuomilehto et al., 2001). One potential reason why obesity may be a trigger for type 2 diabetes is due to the increase of visceral fat in obese individuals. Studies report that central obesity as estimated indirectly by skin folds or waist hip ratio was predictive of the development of type 2 diabetes (Ohlson et al., 1995). Insulin sensitivity improves with weight loss, increasing to a great extent when abdominal fat and waist hip ratio decreases (Holte, Bergh, Berne, wide and Lithell, 1995). In addition, Long et al. (1994) reported that obese subjects with impaired glucose tolerance delayed the progression to type 2 diabetes by losing weight. Most of the Latina women with diabetes have type 2 diabetes and tend to be overweight or obese (Lunt, 1996, Office on Women's Health, 1998, Diabetes Mellitus in Hispanic Women), and most of these women have a previous history of gestational diabetes mellitus. Latina women with a diagnosis of GDM and who have impaired glucose tolerance in the postpartum period have an $80 \%$ risk of developing type 2 diabetes within 5 years (Kjos et al. 1995).

\section{Physical Activity}

Exercise has a beneficial effect on insulin action by enhancing peripheral tissue glucose uptake (Hollenbeck et al., 1984). Further improvement in insulin action may be 
realized by decreasing abdominal fat mass and ameliorating the detrimental effect this has on insulin sensitivity (Erickson, Taimela and Koivisto, 1997). Regular, mild to vigorous exercise has the potential to reduce the risk of type 2 diabetes by $30-50 \%$ (Lynch et al., 1996; Manson and Spelsberg, 1994). Manson et al. (1991) observed a reduced incidence of type 2 diabetes among women who exercise regularly when compared with their sedentary counterparts. The benefits of exercise extend to both obese and non-obese women. Fulton-Keho et al. (2001) studied the impact of physical activity on the Hispanic and non-Hispanic populations and their results suggested that with adjustments for sex, ethnicity, and family history persons with higher levels of physical activity were $25-50 \%$ less likely to develop type 2 diabetes.

Diet

Some studies have shown that a diet higher in fat, especially animal fat is associated with an earlier diagnosis of diabetes in comparison to low fat diets (Dornhorst and Frost, 1997; Mayer-Davies et al., 1997). Moses et al. (1996) reported that the recurrence of GDM was greater in women who consumed more fat between pregnancies. The prevalence of type 2 diabetes increases when the total of calories in the diet derived from fat exceeds $40 \%$ (Marshall, Hamman and Baxter, 1991). Population studies show that habitual high fat diets are associated with hyperinsulinemia, suggesting an increased insulin resistance and long standing insulin resistance would have an adverse cumulative effect on $\beta$-cell reserve increasing the risk for type 2 diabetes (Marshall, Bessesen, and Hamman, 1997; Marshall, Hamman and Baxter, 1991; Feskens et al., 1995). 
Subsequent Pregnancies

Peters et al. (1996) reported that there is a threefold increase in the annual incidence of type 2 diabetes postpartum in Hispanic women previously diagnosed with GDM during subsequent pregnancies. Some findings suggest that although the majority of women have sufficient $\beta$-cell reserves to sustain consecutive pregnancies, women with previous GDM- who already have compromised $\beta$-cell reserves- may not be able to withstand the increased insulin synthesis that future pregnancies demand (Dornhorst and Rossi, 1998).

Breastfeeding

Breastfeeding has been shown to lower blood glucose and decrease the incidence of diabetes in women who had GDM while they were breastfeeding (Kjos et al., 1998; Kjos et. al., 2000; Kjos, Henry, Lee, Buchanan \& Mishell 1993). In addition, breastfeeding has been associated with weight loss and reduced insulin resistance (Brewer, Meredith, Bates and Vannoy, 1989; Dewey, Heining \& Nommsen, 1993). Breastfeeding can assist women in losing weight only if they do not increase their calories postpartum. It is estimated that energy requirements during the first six months of lactation may require an additional $\sim 200$ calories above the pregnancy meal plan. However, an energy intake of $\sim 1800 \mathrm{Kcal} /$ day usually meets the nutritional requirements for lactation and may allow for gradual weight loss (American Diabetes Association, 2003). 


\section{Lactation}

\section{Definition}

Lactation is the process of the synthesis and excretion of milk from the breast to provide nourishment to infants and children.

Incidence

Breastfeeding patterns have changed dramatically over the past 50 years. The incidence of breastfeeding began to decline in the early 1900 s reaching a low of $22 \%$ in 1942 (Eckhardt and Hendershot, 1984). However, by 1982 the incidence had increased to $61.9 \%$ and has remained relatively constant since then (Janke, 1993). In 1998 nationwide survey data indicated that $64 \%$ of mothers reported breastfeeding during the early postpartum period, $29 \%$ at six months, and $16 \%$ at one year (Ross Mother's Survey, 1999). Currently, The Healthy People 2010 goal for breastfeeding is to increase to at least $75 \%$ the proportion of mothers who breastfeed their babies in the early postpartum period, increase to at least $50 \%$ the proportion of mothers who continue breastfeeding until their babies are five to six months old, and increase to at least $25 \%$ the proportion who breastfeed until their infants are one year old (Healthy People 2010 Objectives, 1999).

Energy and Macronutrients Requirements During Lactation

The Food and Agriculture Organization, World Health Organization and United Nations University (FAO/WHO/UNU, 1985) recommendations for lactation up to six months is an increment of $2.9 \mathrm{MJ} / \mathrm{d}(700 \mathrm{Kcal} / \mathrm{d})$, or $2.1 \mathrm{MJ} / \mathrm{d}(500 \mathrm{Kcal} /$ day $)$ if subsidized by body fat mobilization; after six months, an increment of $2.1 \mathrm{MJ} / \mathrm{d}$ is 
recommended. In the United States, according to the Dietary Reference Intakes (DRI) reported by the Institute of Medicine (2002) the recommendations for lactation in women ranging from ages $19-50$ years old are $11.5 \mathrm{MJ} / \mathrm{d}(2,733 \mathrm{Kcal} /$ day $)$, carbohydrate $210 \mathrm{~g} / \mathrm{d}$, and protein $1.1 \mathrm{~g} / \mathrm{kg}$ of body weight. The recommended dietary ranges for adults suggest that 45 to $65 \%$ of their total calories should be from carbohydrate, 20 to $35 \%$ from fat and 10 to $35 \%$ from protein. Butte, Wong and Hopkinson (2001) performed a comprehensive approach to assess the energy requirements of lactating women by measuring total expenditure, milk energy output and energy mobilization from tissues stores. The researchers concluded that the total energy requirements were $12+/-1.4 \mathrm{MJ} / \mathrm{d}(2,866$ $\mathrm{Kcal} / \mathrm{d})$. Energy mobilization from tissue stores, $0.65+/-0.97 \mathrm{MJ} / \mathrm{d}(155 \mathrm{kcal} / \mathrm{d})$, subsidized the energy cost of lactation, resulting in net energy requirements of $11.4 \mathrm{t} /$ 1.8 MJ/d (2,722 Kcal/d). However, the Dietary Intake Data from the Continuing Survey of Food Intakes by Individuals (CSFII) $(1994-1996,1998)$ found that the energy consumed by lactating women is considerably lower than the recommended amount with a mean caloric intake of $9.0 \mathrm{MJ}(2,138 \mathrm{Kcal})$. Moreover, observations of well-nourished lactating women in the United States indicate that women can successfully breastfeed their infants on intakes of $8.4-9.2 \mathrm{MJ} / \mathrm{d}(2000-2200 \mathrm{Kcal} / \mathrm{d})$ (Butte, Garza, Stuff, Smith and Nichols, 1984; Manning-Dalton and Allen, 1983). In addition, similar surveys performed on poorly nourished women in Third World countries have shown that appreciable quantities of milk can be produced to nourish a growing infant for a year or more despite energy intakes as low as $6.7-7.6 \mathrm{MJ}(1,600-1,800 \mathrm{Kcal})$ (Durnin, 1980; Prentice, Whitehead, Roberts and Paul, 1981; Schutz, Lechting and Bradfiel, 1980). In 
conclusion, such data suggest that the recommendations of $2,700 \mathrm{kcal} / \mathrm{d}$ for lactating women may be too high and may not facilitate postpartum weight and fat loss, especially in overweight or obese women. Benefits of Breastfeeding

The health, nutritional, and psychological benefits of breastfeeding are widely acknowledged. The health benefits to the infant and to the mother are summarized in Table 1. In recognition of these benefits, breastfeeding is the infant-feeding method recommended by the American Academy of Pediatrics, the American Public Health Association, and the American Dietetic Association for the first four to six months of life (Saunders, Carrol and Johnson, 1988).

\section{Breastfeeding and Diabetes Mellitus}

Women with diabetes during pregnancy, whether they have GDM, type 1, or type 2 diabetes, should be encouraged to breastfeed their infant. Studies now indicate that breastfeeding reduces the incidence of diabetes in both mothers and their children.

Women with GDM who decide to breastfeed may delay their onset of type 2 diabetes and infants from diabetic mothers who are breastfed may also experience a decrease in the risk of developing diabetes.

\section{Breastfeeding and Type 1 Diabetes in Children}

Godoy et al. (1997) and Agostinho et al. (1997) suggested that exclusive breastfeeding had a possible protective role in the development of type 1 diabetes in children. These researchers suggest that early exposure to cow's milk is a risk factor for the disease and by breastfeeding the infant; the mother will delay the exposure to cow's 
milk and reduce the risk for development of type 1 diabetes in the infant. In addition, Varrala et al., (1999) and Gerstein (1994), have also suggested that breastfeeding the children of type 1 diabetic women and not exposing them to cow's milk in the first year of life, lowered the risk of type 1 diabetes in their offspring. Breastfeeding and Type 2 Diabetes in Children

Infants of women with type 2 diabetes are at higher risk of childhood and adult obesity. Breastfeeding may reduce this risk, as breastfed children tend to be leaner than formula fed children according to Pettit et al. (1997). The study by Pettit et al (1997) concluded that exclusively breastfeeding for the first two months of life is associated with a significantly lower rate of type 2 diabetes in Pima Indians. He suspects that similar findings may be expected in other populations with high rates of young onset of type 2 diabetes.

Beneficial Effect on Glucose Metabolism

One possible scientific explanation offered as to why breastfeeding may have an effect on blood glucose is the need for glucose in the mammary gland when breast milk is synthesized. A full term infant will receive 90 to $270 \mathrm{ml} /$ day from the first to third postdelivery day. By the end of the first week, milk production reaches $420 \mathrm{ml}$; and by days 28 to 30 it exceeds $600 \mathrm{~m} /$ day (McGanity, Dawson \& Van Hook, 1998). The composition of the macronutrients in breast milk is protein $(1.5 \%)$ in the form of lactalbumin and casein, fat (3.5\%) as fine droplets, and carbohydrate (7.0\%) in the form of lactose. The estimated mean concentration of lactose per liter of mature breast milk is $72 \mathrm{~g}$ (McGanity, Dawson \& Van Hook, 1998). The only sugar in milk is lactose and in 
order to synthesize lactose, glucose needs to be available. Therefore, glucose is critical to the volume of milk produced and is used in the production of lactose. Lactose is composed of one molecule of glucose and one molecule of galactose. Since galactose is synthesized from glucose, both monosaccharides in lactose are essentially derived from glucose. In the lactating mammary gland the enzyme lactose synthase participates in the synthesis of lactose. Immediately after a female gives birth, lactose synthase transfers the galoctosyl group of UDP-galactose to glucose at a very high rate, thus making lactose:

UDP-D-galactose + D-glucose $\rightarrow$ D-lactose + UDP (Lehinger, Nelson \& Cox, 1993). Glucose in the mammary gland is derived primarily from plasma glucose, and glucose utilization is increased by $30 \%$ in exclusively breastfeeding mothers due to lactose synthesis (Lawrence and Lawrence, 1999).

In addition, a woman who is breastfeeding during the first three months produces approximately $850 \mathrm{ml}$ of milk per day containing roughly $3 \mathrm{~kJ}(0.7 \mathrm{Kcal})$ energy $/ \mathrm{ml}$. The energy cost of producing $850 \mathrm{ml}$ of milk per day will be $3.14 \mathrm{MJ}(750 \mathrm{Kcal}) /$ day (The Food and Agriculture Organization, World Health Organization and United Nations University, 1985). Another study suggested that breastfeeding during the first three months has an energy cost of 600-650 Kcal/day (Raaij, Schonk, Vermaat-Miedema, Peek and Hautvast, 1991). More recently Butte, Wong and Hopkinson (2001) calculated the energy requirements of lactating women by measuring total energy expenditure, milk energy output, and energy mobilization from tissue stores. These researchers concluded that the total energy expenditure was $10.01 \pm 1.47 \mathrm{MJ} / \mathrm{d}(2,390 \mathrm{Kcal} / \mathrm{d})$ and milk energy 
output was $2.02+/-0.33 \mathrm{MJ} / \mathrm{d}(240 \mathrm{Kcal} / \mathrm{d})$, with an estimated total energy requirement of $12.04+/-1.44$ ( $2875 \mathrm{Kcal} /$ day). Energy mobilization from tissue stores was $0.65+/$ $0.97 \mathrm{MJ} / \mathrm{d}(155 \mathrm{kcal} / \mathrm{d})$, and subsidized the energy cost of lactation, resulting in net energy requirements of $11.4+/-1.8 \mathrm{MJ} / \mathrm{d}(2,722 \mathrm{Kcal} / \mathrm{d})$. Thus, glucose is needed to synthesize lactose as well as a source of fuel for energy utilization in a lactating woman. Therefore, it is assumed that in a lactating woman there is an increase in glucose utilization for both the synthesis of lactose and as a fuel for energy for the nursing mother. There are few studies that have addressed the effects of breastfeeding on blood glucose concentrations in women with GDM. Five studies have looked at the effects of breastfeeding in women with type 1 diabetes, while no study was found on women with type 2 diabetes, and only a single study addressed the effects of breastfeeding in women with previous history of GDM. The studies that looked at the effects of breastfeeding in type 1 diabetic women assessed glucose metabolism by measuring their insulin administration, while the one study conducted in women with a previous history of GDM did not assess daily glucose regulation, and none of the studies addressed the frequency of breastfeeding nor mentioned diet, exercise, day-long blood glucose concentrations, weight, body mass index (BMI) or age of the subjects at the same time.

Kjos et al. (1993) looked at the effects of lactation on glucose metabolism in women with recent gestational diabetes. The mean age, parity, and BMI did not differ significantly between the lactating and non-lactating group. Ninty-five $\%$ of the women were of Latina origin or descent. The 809 women were studied between 4 to 12 weeks after delivery and their testing consisted of a 2 -hour, $75-\mathrm{g}$ oral glucose tolerance test. 
Kjos et al. (1993) found that lactating women had improved glucose tolerance as indicated by a significantly lower area under the glucose curve, with lower fasting and 2hour glucose levels compared to the non-lactating group. However, this study by Kjos et al. (1993) did not define the individuals studied, and the period of breastfeeding was not defined nor the amounts and frequency of breastfeeding. In addition, no data on ambient or day-long glucose control was provided and the period of testing 2-hour glucose tolerance test was not well defined, ranging from 4 to 12 weeks, with no clear estimate of how many completed four weeks and how many 12 weeks postpartum.

Davies, Clark, Dalton and Edwards (1989) found in type 1 diabetic women that after delivery, breastfeeding women needed to reduce their insulin dose by $27 \%$ of their pre-pregnancy dose to avoid hypoglycemic reactions. In addition, Davies et al. (1989) observed that the control of blood glucose concentrations in the breastfeeding women was good despite the reduced insulin dose and increased carbohydrate intake by more than half. Davies et al (1989) did not mention in his study the ethnicity of the women nor the other factors that could affect blood glucose control such as age, body mass index (BMI) and diet. Whichelow and Doddridge (1983) found in type 1 diabetic women that at three months after delivery the mean daily insulin requirement was 43 units compared with 50 units before pregnancy in mothers who were bottle-feeding. Mothers who were breastfeeding also had lower insulin levels ( 40 units compared to 45 units before pregnancy) despite the increased carbohydrate allowance. Whichelow and Doddridge (1983) performed their study with English women from the non-manual social class ranging from 23-40 years of age. Ferris et al. (1988) performed research to document the 
incidence and management of breastfeeding among women with type 1 diabetes. In this study 30 type 1 mothers and 30 controls were followed from birth of their infants to six weeks postpartum. The controls were matched through a random chart review according to age, method of delivery, medications used during delivery, infant sex, method of feeding, maternal parity, pre-conceptual weight, and education. Ferris et al. (1988) found that type 1 diabetic mothers who exclusively breastfed had lower fasting blood glucose levels by 42 days postpartum, even though they had higher caloric intakes when compared to women who stopped breastfeeding. Murtaucgh, Ferris, Capacchione and Recee (1998) conducted a study to describe glycemia and insulin administration in lactating women with type 1 diabetes and compared their energy intake, lactation onset, and postpartum weight to lactating women without diabetes. They studied 14 lactating women with type 1 diabetes and 25 women without diabetes (control subjects) who provided complete dietary records. Maternal age, education, parity, pre-pregnancy weight, pregnancy weight gain and weight of infant at birth did not differ between the control and subgroup of 14. Murtaucgh et al. (1998) found that seven women with type 1 diabetes breastfed through 84 days postpartum although they perceived later onset of milk and had fasting and post-prandial hyperglycemia. After adjusting for pre-pregnancy weight, women with type 1 diabetes consumed $7 \mathrm{kcal}$ fewer per kilogram per day than control subjects. The average insulin dose was returned to pre-pregnancy levels by one week. This study did not compare the effects of breastfeeding on insulin requirements and blood glucose control between Type 1 diabetic women and non-breastfeeding type 1 diabetic women. Yang, Xu and Gai (1994) recruited 37 cases of type 1 diabetic Chinese 
mothers and 10 gestational diabetic Chinese mothers requiring regular insulin for treatment during pregnancy. Yang et al. (1994) conducted a comparative study of the daily regular insulin requirements between women breastfeeding and non-breastfeeding. Yang et al. (1994) found a significant decrease of regular insulin among breastfeeding mothers in the postpartum period for the type 1 diabetic mothers and gestational diabetic mothers who breastfed did not need any regular insulin after delivery with blood glucose levels remaining within normal range.

In conclusion, some studies have reported that women with gestational and type 1 diabetes who breastfed had better glycemic control compared with those who formula fed. However, the literature review did not show any evidence of studies done on the effects of breastfeeding on day-long blood glucose regulation in overweight/obese Latina women with a history of GDM who exclusively breastfed for at least three months. It is hypothesized that lactation, which has been associated with beneficial effects on glucose regulation in the postpartum period in type 1 diabetic women and recent gestational diabetic women, should similarly affect overweight or obese Latina women with a history of GDM. 


\section{Table 1}

Health Benefits of Breastfeeding to the Infant and to the Mother

\begin{tabular}{|c|c|}
\hline Benefits to the Infant & Benefits to the Mother \\
\hline $\begin{array}{l}\text { 1. Breastfeeding enhances the immune system and } \\
\text { resistance to infection. } \\
\text { 2. Breastfeeding is protective against infant botulism. } \\
\text { 3. Breastfeeding may reduce the risk for subsequent } \\
\text { inflammatory bowel disease and childhood } \\
\text { lymphoma. } \\
\text { 4. Breastfeeding reduces the incidence and lessens } \\
\text { the severity of bacterial infections such as meningitis, } \\
\text { lower respiratory illnesses, bacteremia, and ear } \\
\text { infections. } \\
\text { 5. Breastfed infants are less likely to have diarrhea. } \\
\text { 6. Fatty acids, unique to human milk, may play a role } \\
\text { in infant brain and visual development. } \\
\text { 7. Breastfeeding protects against allergies. } \\
\text { 8. Breastfeeding protects against sudden infant death } \\
\text { syndrome. }\end{array}$ & $\begin{array}{l}\text { 1. Breastfeeding helps the uterus to shrink to } \\
\text { its pre-pregnancy state and reduces the } \\
\text { amount of blood lost after delivery. } \\
\text { 2. Breastfeeding mothers return to their pre- } \\
\text { pregnant weight more rapidly than bottle } \\
\text { feeding mothers. } \\
\text { 3. Breastfeeding may reduce the risk of } \\
\text { osteoporosis. } \\
\text { 4. Breastfeeding reduces the risk of breast and } \\
\text { ovarian cancers. } \\
\text { 5. Breastfeeding improves lipid and glucose } \\
\text { metabolism during the postpartum period. } \\
\text { 6. Women who breastfeed their infants are } \\
\text { less likely to develop multiple sclerosis. } \\
\text { 7. Breastfeeding promotes maternal } \\
\text { confidence. }\end{array}$ \\
\hline
\end{tabular}

Note. From "Breastfeeding: Investing in California's Future" by the Breastfeeding Promotion Committee Report to the California Department of Health Services Primary Care and Family Health, 1996, p. 7-15. 
CHAPTER II

JOURNAL ARTICLE 
Title: Effects of Breastfeeding on Blood Glucose Regulation among Overweight/Obese Latina Women with a History of Gestational Diabetes Mellitus Manuel F. Villacorta, $\mathrm{MS}^{1}$, Clarie B. Hollenbeck, $\mathrm{PhD}^{1}$, Yolanda M. Gutierrez PhD, MS, $\mathrm{RD}^{2}$, Yasser El Sayed, $\mathrm{MD}^{3}$, Leona Dang-Kilduff, RN, MSN, CDE${ }^{2}$, Lucy M. McProud $\mathrm{PhD}, \mathrm{RD}^{1}$

\author{
'Department of Nutrition and Food Science, San Jose State University, San Jose \\ California \\ ${ }^{2}$ Mid-Coastal California Perinatal Outreach Program, Stanford University, Stanford, \\ California \\ ${ }^{3}$ Department of Obstetrics, Stanford University, Stanford, California
}

Address all correspondence and reprint request to:

\author{
Manuel F. Villacorta, MS \\ c/o Clarie B. Hollenbeck, PhD \\ Department of Nutrition and Food Science \\ San Jose State University \\ One Washington Square \\ San Jose, CA 95192-0058 \\ Tel: (408) $924-3100$ \\ FAX: (408) 924-3116 \\ E-mail: Villacorta@onebox.com
}

Running title: Lactation and Gestational Diabetes 


\begin{abstract}
Effects of Breastfeeding on Blood Glucose Regulation among Overweight/Obese Latina women with a History of Gestational Diabetes Mellitus M.F. Villacorta, C.B. Hollenbeck, Y.M. Gutierrez, Y. El Sayed, L. Dang-Kilduff, L.M. McProud. Department of Nutrition and Food Science, San Jose State University, San Jose, California. Stanford University, Stanford, California

OBJECTIVE: To examine the effects of breastfeeding on day-long (fasting, 1 hour post-breakfast, lunch, dinner, and before bed time) blood glucose regulation during the first three months postpartum in Latina women with a history of gestational diabetes mellitus (GDM).
\end{abstract}

RESEARCH DESIGN AND METHODS: A total of 20 Mexican-American women from the California Diabetes and Pregnancy Program participated in the 12-week postpartum study. Subjects required a diagnosis of GDM and to be between 20 and 45 years of age. Capillary plasma blood glucose was measured by a home blood glucose monitor (FreeStyle) five times per day, three days per week during the entire study period. Random capillary plasma blood glucose levels from the day of delivery were obtained from medical records. Women who chose to breastfeed were required to record the number of times/day they breastfed on the same days that they were monitoring their blood glucose levels. Three-day maternal food records were completed by all of the participants for each of the 12 weeks of the study. Maternal and infant weights and maternal BMI were assessed at 6 weeks and 12 weeks postpartum. Repeated 
measurements were analyzed using a general linear model and linear regression and the means were compared using independent t-test.

RESULTS: Of the 20 women, 13 women chose to exclusively breastfeed (BF), 5 women chose to formula-feed $(\mathrm{FF})$ and 2 chose to use a combination of breastfeeding and formula feeding. The present study reports data on those individuals who exclusively breastfed or formula fed their infants. Blood glucose levels on the day of delivery were not significantly different between the groups. Fasting blood glucose levels (FBG) were significantly higher as the weeks progressed in both groups $(\mathrm{p}=0.0)$. In addition, there were differences between the groups in both fasting glucose concentration and rate of change in fasting glucose concentrations over the 12-week study period $(P=0.001)$. The rate of change in FBG increased at a lower rate in the BF group $(0.836 \mathrm{mg} / \mathrm{dl} ; P=0.008)$ than in the FF group ( $1.94 \mathrm{mg} / \mathrm{dl} ; P=0.002)$ over the 12 weeks of the study. The average of the 5 measurements of one day was calculated and is defined as ambient blood glucose (AMBG). AMBG levels were significantly lower in the BF group than the FF group over the 3 month period $(P=0.001)$. As the weeks progressed the AMBG also increased significantly, and the rate of change in AMBG for the BF group was 0.497 $\mathrm{mg} / \mathrm{dl} /$ week $(P=0.007)$ versus $0.691 \mathrm{mg} / \mathrm{dl} /$ week for the FF group $(P=0.06)$. The kilocalories from the BF group increased significantly as time progressed over the 12 week period $(\mathrm{P}=0.001)$ and the kilocalorie intake was significantly higher in the $\mathrm{BF}$ than the FF only during the mid weeks of the study $(P=0.003)$.

CONCLUSIONS: These data support the notion that breastfeeding contributes to the improvement of blood glucose regulation in Latina women with previous history of 
GDM during the first 3 months postpartum. Thus, these data suggest that breastfeeding may be providing a modicum of protection for Latina women with previous history of GDM in their progression toward type 2 diabetes. This study also provides added clarity of the regulation of glucose metabolism in the immediate months postpartum in Latina women experiencing GDM.

\section{Introduction}

Diabetes is a major cause of morbidity and mortality in the United States (1). The estimated prevalence of diabetes among the general population was $7.4 \%$ in 1995 and this is expected to rise to $\sim 9 \%$ by 2025 (2). In the United States, minority groups have substantially higher rates of diabetes than Caucasian individuals $(3,4)$. In the Hispanic Health and Nutrition Examination Survey of 3,928 Mexican-Americans ages 20-74 years, the age-adjusted prevalence of self-reported diabetes was $6.8 \%$ among men and $7.6 \%$ among women (5). Comparable age-adjusted prevalence for the U.S. population in a similar national survey was $2.9 \%$ in men and $3.8 \%$ in women (5).

The prevalence of diabetes in almost all age groups is higher among women than men. Most of the Latina women with diabetes have type 2 diabetes and they tend to be overweight $(6,7)$. Latina women who developed type 2 diabetes generally have a previous history of gestational diabetes mellitus (GDM). Latina women who experience GDM and who remain impaired glucose tolerant in the postpartum period have a $80 \%$ risk of developing type 2 diabetes within 5 years (8). However, a woman with a history of GDM can decrease the risk of developing type 2 diabetes by making relatively simple lifestyle changes. Studies have shown that weight control, as well as change in diet and 
exercise, can help lower the risk of development of type 2 diabetes in women with a history of gestational diabetes (9-11). Breastfeeding may also play an important role in helping women with a history of GDM to decrease the risk of developing type 2 diabetes. Breastfeeding is associated with weight loss, leading to a reduction in insulin resistance (12-13). Breastfeeding requires more calories $(14,15)$; overweight and obese women who do not increase their calories while breastfeeding would likely experience weight reduction (12). Finally, lactation may have a beneficial effect on blood glucose metabolism independent of calorie expenditure and weight loss that may lead to lower blood glucose concentrations. For these reasons it is believed that breastfeeding may provide protection for women in delaying the onset of type 2 diabetes (16-19).

Most studies on lactation have focused on the quality and quantity of milk produced or on the effects of breast milk on infants. Relatively little attention has been given to the mother and her needs. Therefore, the purpose of the present study was to examine the effects of breastfeeding on day-long (fasting, 1 hour post-breakfast, lunch, and dinner and before bed time) blood glucose regulation during the first three months postpartum in Latina women with a history of GDM. The results of this study will provide insight into the ability of breastfeeding to return daylong glucose regulation to normal as well as a profile of how quickly these individuals re-establish normal glucose regulation. 


\section{Research Design and Methods}

\section{Subiects}

Twenty Mexican-American women participating in the California Diabetes and Pregnancy Program (Sweet Success Program) from the Obstetric Clinic at Stanford University School of Medicine were recruited for the present study. Details of the study were explained to all participants and written consent was obtained in accordance with procedures outline by the Committee on Human Subjects-Institutional Review Boards of Stanford University and San Jose State University. Pregnant Latina women with gestational diabetes were recruited during one of their prenatal visits between August 2002 and December 2002. All of the women had MediCal as their sole or primary medical insurance. Subjects with GDM between 20 and 45 years of age were recruited for the study. Women who agreed to participate in the study were visited at their home one month before their estimated due date to explain the procedures necessary to accurately complete their blood glucose log sheet, three-day food record, and breastfeeding records. A detailed family history questionnaire was used to obtain information on socioeconomic and educational background, previous pregnancies, prepregnancy weight, height, method of treatment of GDM (insulin and/or diet therapy), and method of delivery (vaginal or C-section). All women were instructed to call within two days of arrival at home after delivery. 


\section{Data Collection}

All subjects were visited in their home every 2 weeks for 12 weeks beginning the first week they returned home from the hospital after delivery. A nutritionist/certified lactation educator collected and reviewed the data during each visit to provide clarity and assure accurate data collection.

\section{Blood Glucose}

\subsection{Day of Delivery Random Capillary Blood Glucose}

All women had random blood glucose concentrations measured as a routine admissions screening procedure. Random capillary plasma glucose concentrations were obtained from medical records for the day of delivery.

\subsection{Capillary Plasma Blood Glucose}

All of the women were asked to continue to monitor their blood glucose levels with the same glucose monitor that was used throughout their pregnancy. Capillary plasma glucose was measured by an automated blood glucose monitor (FreeStyle by Therasense) five times per day, three days per week (Tuesday, Thursday, and Saturday) throughout the entire study period. The same three days were chosen for all individuals to provide consistency. The women were required to check their blood glucose in the following manner: in the morning before breakfast (fasting), 1 hour post-prandial (breakfast, lunch, and dinner) and before bedtime. 


\subsection{Ambient Blood Glucose}

For the purpose of this study ambient blood glucose (AMBG) is defined as:

$A M B G=(F B G+1 h$ pp breakfast +1 pp lunch + Ih pp dinner + before bed $) / 5$

Where:

- $\quad F B G=$ Fasting blood glucose level (mg/dl).

- $1 \mathrm{~h} p \mathrm{p}=1$ hour post-prandial blood glucose levels $(\mathrm{mg} / \mathrm{dl})$.

- Before bed $=$ blood glucose level before bed time $(\mathrm{mg} / \mathrm{dl})$.

All women recorded their results on a blood glucose log sheet provided during the prenatal home visit. The glucometers used were capable of storing the date, time and the blood glucose concentrations over the entire period of study, thus facilitating reliable and accurate data collection.

\section{Method of Infant Feeding}

Participants were assigned to one of the three groups according to the method of infant feeding employed during the three months postpartum period: exclusive breastfeeding (BF), exclusive formula feeding (FF), and combination breastfeeding and formula feeding $(\mathrm{CF})$. Women from the $\mathrm{BF}$ and $\mathrm{CF}$ groups were required to record the number of times/day they breastfeed on the same days (Tuesday, Thursday, and Saturday) that they were monitoring their blood glucose levels. Women who were breastfeeding were assisted in their home by a certified lactation educator (CLE) 
throughout the duration of the study in order to identify and evaluate any potential problems encountered during breastfeeding.

\section{Energy and Macronutrient Intake}

Three-day maternal food records (Tuesday, Thursday and Saturday) were completed by all of the participants for each of the 12 weeks of the study. Subjects were instructed to keep records of amounts, types and methods of preparation of the foods and beverages consumed on the days they were recording their blood glucose levels and frequency of breastfeeding. The nutritionist reviewed the three-day food records with each subject during home visits to make sure they were completed accordingly. For purposes of clarity and to increase reliability and eliminate any ambiguity in their responses, each subject was asked to show their household measures, serving sizes, and brands of food consumed during the study period. Although 3-day food records were collected for every week of the study, only 3-day food records from weeks $1,2,6,7,11$ \& 12 were analyzed. Women were not informed as to which weeks would be analyzed in order to maintain consistency and to eliminate any unintentional bias in their dietary intake throughout the study period. A total of six 3-day food records (18 days) for each woman was analyzed. Energy intake (Kcal), protein $(\mathrm{g})$, carbohydrate $(\mathrm{g})$ and fat $(\mathrm{g})$ intake were calculated using the computer software Nutritionist Pro (First DataBank, Inc.). 


\section{Anthropometry}

Matemal weight was measured at 6 and 12 weeks postpartum using a digital scale (Thinner MS-7400). Participants were weighed in light clothing without shoes. Prepregnancy weight and height was extracted from medical records if pre-pregnancy weight or height was not reported on the questionnaire.

Infant weight was measured at 6 and 12 weeks of age using an infant digital scale (Tanita 1584). Infant's weights were obtained at the same time as matemal weights. Infant birth weight was obtained from medical records if not previously recorded by the mother.

\section{Statistical Analysis}

All data analyses were conducted using SPSS 11.0 for windows. Subjects were grouped by method of feeding for comparisons. Maternal age, gravida, parity, number of times that women experience GDM, level of education, BMI, maternal weights and infant weights, and blood glucose concentrations from day of delivery were compared using the independent T-test. Matemal weights were also analyzed by repeated measures general linear model.

Repeated measurements of FBG and AMBG levels were analyzed by general linear model and linear regression. The frequency of breastfeeding over time was analyzed by linear regression and the frequency of breasteeding per week was analyzed by descriptive statistics. 
The energy and macronutrient intakes were divided into three different times, first two weeks (FW), mid weeks (MW) and last two weeks (LW). Repeated measurements of Kcal and grams of macronutrients were analyzed using a general linear model and linear regression, and the means were compared using independent t-test. The distribution \%ages of the macronutrients were analyzed by a general linear model and the mean \%ages were compared using an independent t-test. Data are presented as mean SD and the level of statistical significance was set at $p<0.05$. In most cases actual $p$ values are reported.

\section{Results}

The mean age, parity, level of education, and BMI before pregnancy did not differ significantly between the BF and FF groups (Table 1). The formula feeding group had a significantly higher incidence of pregnancy than the breastfeeding group $(2.8 \pm 0.9$ versus $4.2 \pm 1.9 ; P=0.045)$, but did not differ in number of births. In general, the study group was overweight with a mean pre-pregnancy BMI of $27.6 \pm 4 \mathrm{~kg} / \mathrm{m}^{2}$. All of the women were immigrants from Mexico living in San Mateo County, California.

Of the 20 women who participated in the study, 13 women chose to exclusively breastfeed their infants, 5 women chose to exclusively formula-feed and 2 women chose a combination of breastfeeding and formula feeding. Data for combination feeding were collected, but not included in the present analysis. Of the 13 women who breastfed, 5 were treated with insulin during pregnancy, 8 with diet therapy. Two of the $13 \mathrm{BF}$ women delivered by $\mathrm{C}$-section, while the rest delivered by vaginal delivery. Of the 5 women in the formula-feeding group, 4 were treated with insulin during pregnancy, 1 
with diet therapy. All FF women had normal vaginal deliveries. None of the women in this study claimed to be dieting nor exercising during the time of the study. All of the women were house bound caring for the new infant during the period of the study.

The blood glucose levels from the date of delivery were not significantly different between the groups ( $93 \pm 15 \mathrm{mg} / \mathrm{dl}$ versus $95 \pm 9 \mathrm{mg} / \mathrm{dl}$ ). The mean FBG levels throughout the 12 weeks of the study were lower $(p=0.001)$ in the BF group than the FF group (Table 2). A steady but significant increase in the mean FBG levels (Figure 1) occurred in both groups over the 3-month postpartum period. Fasting blood glucose concentrations increased at a lower rate in the BF group than the FF group over the 12 weeks of the study $(0.836 \mathrm{mg} / \mathrm{dl}$ versus $1.94 \mathrm{mg} / \mathrm{dl} ; P=0.008$ versus $P=0.002)$.

Ambient blood glucose levels (Table 3) were significantly lower in the BF group than the FF group over the 3 months postpartum $(P=0.001)$. As the weeks progressed the $A M B G$ also increased significantly but at a lower rate than the FBG levels (Figure 2). The rate of incremental increase in AMBG for the BF group was $0.497 \mathrm{mg} / \mathrm{dl} /$ week $(P=$ $0.007)$ and $0.691 \mathrm{mg} / \mathrm{dl} /$ week $(P=0.06)$ for the FF group.

The mean frequency of breastfeeding per week was not significantly different among the breastfeeding subjects. The mean frequency of breastfeeding started to increase by weeks 3 and began to decline by week 6 (Figure 3 ).

The kilocalories from the BF group (Figure 4) increased significantly as time progressed over the 3 -month period $(1,724 \pm 551 \mathrm{Kcal}$ to $1969 \pm 501 \mathrm{Kcal} ; P=0.001)$. The kilocalories from the FF group changed significantly in a non-linear manner; 
decreasing during MW $(1,781 \pm 489 \mathrm{Kcal}$ to $1641 \pm 395 \mathrm{Kcal})$ and increasing during $\mathrm{LW}$ $(1917 \pm 500 \mathrm{Kcal})$. Kilocalories (Table 4) from FW $(1,724 \pm 551 \mathrm{Kcal}$ versus $1781 \pm 489$ Kcal $)$ and LW (1969 $\pm 501 \mathrm{Kcal}$ versus $1917 \pm 500 \mathrm{Kcal})$ were not significantly different, but MW kilocalories were significantly different between the BF and FF groups (1970 $537 \mathrm{Kcal}$ versus $1641 \pm 395 \mathrm{Kcal} ; P=0.003$ ). The amount of protein (Table 5) did not changed significantly over time but the amounts of carbohydrate $(P=0.001)$ and fat $(P=$ $0.04)$ changed significantly with time in both groups. Moreover, the amounts of carbohydrate (Table 6) were significantly higher during the MW (262 $\pm 69 \mathrm{~g}$ versus 217 $\pm 58 \mathrm{~g} ; P=0.002)$ in the BF group than the FF group. The amounts of fat (Table 7) were also significantly higher in the BF than the FF group during the MW $(67 \pm 29 \mathrm{~g}$ versus 53 $\pm 20 \mathrm{~g} ; P=0.02)$.

The $\%$ distribution of calories from protein, carbohydrate and fat did not change significantly over time in either group, and there were no significant differences between the groups during the entire study period (Figure 5).

The infant's weights at birth $(3.5 \pm 0.3 \mathrm{~kg}$ versus $3.3 \pm 0.4 \mathrm{~kg}), 6$ weeks $(5.1 \pm 0.5$ $\mathrm{kg}$ versus $4.7 \pm 0.4 \mathrm{~kg})$ and 12 weeks $(6.3 \pm 0.6 \mathrm{~kg}$ versus $5.8 \pm 0.6 \mathrm{~kg})$ were not significantly different between the groups (Table 8). Maternal weights (Table 9) at prepregnancy $(66 \pm 12.3 \mathrm{Kg}$ versus $68 \pm 4.5 \mathrm{Kg}), 6$ weeks $(67 \pm 13.2 \mathrm{Kg}$ versus $67 \pm 4.1 \mathrm{Kg})$ and 12 weeks $(68 \pm 13 \mathrm{Kg}$ versus $68 \pm 4.5 \mathrm{Kg}$ ) postpartum were also not significantly different between the BF and FF groups. Maternal BMI (Table 10) at pre-pregnancy (27 $\pm 4.8 \mathrm{~kg} / \mathrm{m}^{2}$ versus $\left.27.9 \pm 1 \mathrm{~kg} / \mathrm{m}^{2}\right), 6$ weeks postpartum $\left(27.4 \pm 4.7 \mathrm{~kg} / \mathrm{m}^{2}\right.$ versus $27.4 \pm$ $\left.2 \mathrm{~kg} / \mathrm{m}^{2}\right)$ and 12 weeks postpartum $\left(28 \pm 4.8 \mathrm{~kg} / \mathrm{m}^{2}\right.$ versus $\left.27.6 \pm 1.9 \mathrm{~kg} / \mathrm{m}^{2}\right)$ were not 
significantly different between the BF and FF groups. However, both groups experienced a significant increase in weight and BMI from week 6 to week 12 postpartum $(P=0.05)$.

\section{Discussion}

The results of the present study provide important insights into several areas in the management of overweight or obese women with gestational diabetes. First, the results of the present study clearly indicate that overweight/obese Mexican-American women with a history of GDM who chose to breastfeed their infants for the first 3 months postpartum establish more efficient glucose regulation than the non-lactating women. Both fasting blood glucose (FBG) and ambient blood glucose (AMBG) levels throughout the 12 weeks of the study were significantly lower in the lactating women when compared to non-lactating women. These observations are in accordance with an early study done in women with recent GDM (17). Second, in the present study we found that both FBG and AMBG levels were increasing over the 12 weeks of the study in both groups. However, this rate of increase was significantly less in the lactating women when compared to the non-lactating women. Third, the lactating women from this study did not meet the DRI recommendations for calories (14) and yet still gained weight.

There are several possible explanations that could account for the improvement of blood glucose regulation among the lactating women. One explanation that has been offered to explain the improvements noted in glucose metabolism has been based on the notion that breastfeeding substantially increases calorie needs. If women do not replace these calories in their diet, this would facilitate weight loss and potentially increased insulin sensitivity $(12,13)$. However, in the present study, with the exception of the 
increased calorie intake associated with increased lactation observed with the mid-study sampling, there were no significant differences in calorie intake or weight gain that could account for the improvement in glucose metabolism. Weight gain appeared continuous throughout the 12-weeks of the study and did not differ significantly between the two groups. The average weight gain from the 6 -week measurement to the 12 -week measurement was $2 \mathrm{lbs}$, or approximately $1.3 \mathrm{lbs}$ per month. By the $12^{\text {th }}$ week both groups had equaled or exceeded pre-pregnancy weights, and it is not clear if weight gain would have ceased. Nevertheless, it indicates that breastfeeding did not impact postpartum weight gain observed in overweight/obese women with GDM. The only significant difference in energy intake between the two groups occurred in the mid weeks of the study and was associated with increased frequency of breastfeeding accompanying the first of the expected infant growth spurts. It is possible that the beneficial aspects of breastfeeding on matemal weight gain reported in the literature $(12,13)$ are not realized until later in the postpartum period. Although not a specific aim of the present study, the data suggest that the energy cost of milk production in the first 3 months of lactation may be substantially less than the recommended $2700 \mathrm{kcal} / \mathrm{day}$, and raises the question of whether or not following the current recommendations would have resulted in significant weight gain in these women with GDM.

Another possible explanation for the observed improvements in glucose metabolism is that lactation per se may have increased insulin sensitivity and/or $\beta$ cell function in these women during the postpartum period (20). Studies using a rodent model have demonstrated that lactating rats have increased insulin sensitivity, lower blood 
glucose and insulin levels during lactation and similar effects may also occur in humans (21-23). The present study did not look at changes in insulin action or $\beta$ cell function in these women and, thus, we cannot specifically address that issue. However, it may not be necessary to evoke changes in insulin action on insulin sensitive tissues to explain the difference noted in blood glucose regulation in the present study. The skeletal muscle is the major site of insulin sensitive glucose disposal, and skeletal muscle as well as adipocytes use GLUT 4, which requires insulin binding for glucose transport. On the other hand, glucose is transported into the mammary tissue via GLUT 1 and SGLT 1 transporters (24). Since both of these transport systems transport glucose independent of insulin binding, enhanced uptake of glucose into mammary tissues is not dependent on increased insulin sensitivity.

Glucose is not only necessary to provide energy for milk production during lactation, but it is also needed in mammary tissue as substrate in the synthesis of lactose. A full term infant will receive 90 to $270 \mathrm{ml} /$ day from the first to third post-delivery day; by the end of the first week, milk production reaches $420 \mathrm{ml}$; by days 28 to 30 it exceeds $600 \mathrm{ml} /$ day (26). Estimated milk production of a woman breastfeeding during the first three months is approximately $850 \mathrm{ml}$ milk per day. The macronutrients composition of breast milk is $1.5 \%$ protein in the form of lactalbumin and casein, $3.5 \%$ fat as fine lipid droplets and $7.0 \%$ carbohydrate in the form of lactose. The concentration of lactose of mature breast milk is approximately $72 \mathrm{~g}$ per liter (26). Thus, over the first 3 months of lactation an average of 61 grams of glucose per day would be necessary to support lactose production. It is possible that increased uptake and utilization of glucose by 
mammary cells underlies the attenuation in the rise of $F B G$ and $A M B G$ observed among the women breastfeeding their infants in the present study. The only carbohydrate in breast milk is lactose. Lactose is composed of one molecule of glucose and one molecule of galactose. Galactose is synthesized in mammary cells from UDP-glucose by UPDhexose 4-epimeraseas. The resultant UDP-galactose is bound to D-glucose by lactase synthetase to form lactose.

Another important observation was that both $F B G$ and $A M B G$ levels were increasing over the 12 weeks of the study. This observation implies that women from this study may eventually develop type 2 diabetes over time. However, the rate of increase of FBG and AMBG was significantly less in the lactating women when compared to the non-lactating women. It is estimated that approximately 60 to $80 \%$ of women who experienced GDM develop type 2 diabetes within 5 years $(8,27)$. Woman with GDM demonstrate both insulin resistant and $\beta$-cell dysfunction (27-31) during and after pregnancy. These two traits are strongly associated with the development of type 2 diabetes, and improving insulin sensitivity postpartum theoretically preserves $\beta$-cell function (32), and would be expected to reduce the risk of developing type 2 diabetes in the future. Thus our observations add additional support to the conclusions from other studies that breastfeeding may protect women with a history of GDM by reducing or delaying the risk of developing type 2 diabetes (16-19).

Frequency of breastfeeding in the present study paralleled the patterns of infant growth spurts. The first growth spurts in infants usually occur at around 3-6 weeks and 12 weeks of age (33). In this study we observed an increase in the number of feedings 
starting at 3 weeks with the highest frequency of feedings at 5 weeks. The frequency of breastfeeding began to decline from a mean of 12 times to 10 times per day during the $6^{\text {th }}$ week. The decline of breastfeeding frequency could be explained on the basis that as the infant grows the sucking is stronger and the extraction of milk volume per feeding increases, and thus the infants need less feedings per day. Even though the caloric intakes in the lactating women were not meeting the DRI recommendations (14), they were able to produce enough milk volume to sustain their infant's growth as seen in this study. The infant's weight gains were not significantly different between the groups and both groups gained as expected.

A 3-day food record was found to be an adequate tool for estimating the mean energy values reported by the groups (34). In this study the women recorded 3-day food records for every week of the study. The energy intake for the breastfeeding group increased significantly with time, but the first week's and last week's caloric intake from both groups were not significantly different. During the mid weeks of the study the breastfeeding group had significantly higher intakes of total calories, carbohydrate, and fat than the formula fed group. Moreover, no significant differences were found between the groups in the distribution of macronutrients throughout the study period. In general, both groups met the DRI recommendations for the macronutrient dietary ranges (14). Although 3-day food records are only semi-quantitative and may not be representative of the actual intake, there were strengths in the 3-day food records collected from this study that add substantially to their reliability. Specifically, the food records were reviewed every two weeks with the subjects by a nutritionist and subjects provided examples of 
their household measures used in estimating serving sizes. In addition, they provided the actual brands of foods they consumed throughout the study. All of the subjects were Mexican-American, and had similar food habits. Finally, all of the subjects in the present study were participants in the "Sweet Success Program" and had been keeping detailed three day food records throughout their pregnancy and, therefore, they were all very familiar with keeping dietary records.

The lactating women did not meet the DRI recommendations for kcal during the study (14). The mean age of the lactating mothers in this study was $32 \pm 7$ years and their mean BMI $27.5 \pm 4.7 \mathrm{~kg} / \mathrm{m}^{2}$. Their recommended caloric intake, therefore, would have been between $2,700 \mathrm{kcal} /$ day (14). On the other hand, the estimated caloric intake based on their dietary records was only between $1724 \pm 551$ and $1969 \pm 519$. The 630 to 980 $\mathrm{kcal} /$ day deficit should have resulted in an estimated weight loss of approximately 1.6 $\mathrm{lbs} /$ week, or $19 \mathrm{lbs}$ over the 12 -week study period over the formula fed women. The fact that the estimated weight loss did not occur raises serious questions about whether or not the current recommendations are appropriate for obese women with history GMD. The DRI recommendations are for active women with a healthy weight with a BMI of 20-24 (14). The women from this study were Mexican-American who were following "la cuarentena," six weeks of staying home caring for their new infants and eating mainly chicken soups, oatmeal drinks, and com tortillas. In addition, none of the women were involved in any physical activity during the study period. Therefore, the lack of physical activity could explain the weight gained of the subjects. There is strong evidence that obesity, weight gain, and physical inactivity are main determinants for the development 
of type 2 diabetes $(9,11)$. Although the breastfeeding women in the present study may be receive protection in terms of lower $F B G$ and $A M B G$ and may be delaying the onset of type 2 diabetes, they are still at risk because of their weight and lack of physical activity. Observations of well-nourished lactating women in the United States indicate that women can successfully breastfeed their infants on intakes of $2000-2200 \mathrm{Kcal} / \mathrm{d}$ ( 35 , 36). In addition, moderately undernourished women in developing countries are capable of nourishing a growing infant for a year or more despite energy intakes as low as 1,600$1,800 \mathrm{Kcal} /$ day $(37,39)$. Moreover, an energy intake of $\sim 1800 \mathrm{Kcal} /$ day usually meets the nutritional requirements for lactation and may allow gradual weight loss (2). In brief, such data suggest that the recommendations of $2,700 \mathrm{kcal} / \mathrm{d}$ for lactating women may be too high and it is not facilitating postpartum weight and fat loss, especially in overweight or obese women who are sedentary.

In conclusion, we found that breastfeeding contributed to the improvement of blood glucose regulation in overweight/obese Latina women with a previous history of GDM during the first 3 months postpartum. Breastfeeding may provide protection to these women by slowing the progression toward the development of type 2 diabetes.

\section{Acknowledgments}

This research was supported by TheraSense@ through their donations of test strips and lancets, by San Jose State University College Applied Sciences and Arts Small Research Grant Award, by San Jose State University Department of Nutrition and Food Science Circle of Friends Research Assistance Award, and the Prenatal To Three 
Initiative Program. The authors gratefully acknowledge the invaluable assistance of Julie Postma, Erlinda Stern, Gretchen Flanagan and Tami Enderli with subject recruitment and data collection. Special thanks to the women who participated in this study for their hard work and generous cooperation. 
Table 1

Climical Characteristics of Overweight and Obese Latina Women with a History of Gestationa Diabetes Mellitus*

\begin{tabular}{lccc}
\hline & BF & FF & \\
& $(n=13)$ & $(n=5)$ & $P$ \\
\hline Age $(y)$ & $31.7 \pm 6.7$ & $32.2 \pm 6.7$ & NS \\
Gravida & $2.8 \pm 0.9$ & $4.2 \pm 1.9$ & $0.045+$ \\
Parity & $2.6 \pm 1.0$ & $3.2 \pm 1.6$ & NS \\
Education & $7.4 \pm 2.3$ & $7.8 \pm 4.3$ & NS \\
BMl before pregnancy & $27.4 \pm 4.8 \pm$ & $27.9 \pm 1$ & NS \\
\hline
\end{tabular}

"Data are presented as mean $\pm \mathrm{SD}$

NS= not significant.

TSignificant difference between groups by t-test.

₹ Mean average calculated from 12 breastfeeding women. 


\section{Table 2}

Fasting Blood Glucose in the Breasteeding (BF) and Formula Feeding (FF) Groups by Weck $^{*}$

\begin{tabular}{ccc}
\hline Weeks & $\begin{array}{c}\text { BF } \\
(n=13)\end{array}$ & $\begin{array}{c}\text { FF } \\
(n=5)\end{array}$ \\
\hline FBG-1 & $80 \pm 5$ & $93 \pm 10$ \\
FBG-2 & $86 \pm 6$ & $103 \pm 14$ \\
FBG-3 & $90 \pm 9$ & $99 \pm 7$ \\
FBG-4 & $88 \pm 8$ & $103 \pm 12$ \\
FBG-5 & $86 \pm 8$ & $102 \pm 6$ \\
FBG-6 & $88 \pm 8$ & $101 \pm 8$ \\
FBG-7 & $91 \pm 13$ & $99 \pm 7$ \\
FBG-8 & $97 \pm 13$ & $107 \pm 17$ \\
FBG-9 & $90 \pm 8$ & $110 \pm 15$ \\
FBG-10 & $92 \pm 9$ & $110 \pm 20$ \\
FBG-11 & $93 \pm 12$ & $104 \pm 10$ \\
FBG-12 & $91 \pm 9$ & $110 \pm 16$ \\
\hline
\end{tabular}

"FBG mean $\pm \mathrm{SD}$ in $\mathrm{mg} / \mathrm{dl}$

$\mathrm{n}=$ number of subjects

Significant difference between the groups by repeated measures general linear model ( $P$ $<0.001)$ 
Table 3

Ambient Blood Glucose (AMBG) in the Breastfeeding (BF) and Formula Feeding (FT) Groups by Week"

\begin{tabular}{ccc}
\hline Weeks & $\begin{array}{c}\text { BF } \\
(n=13)\end{array}$ & $\begin{array}{c}\text { FF } \\
(n=5)\end{array}$ \\
\hline AMBG-1 & $100 \pm 16$ & $120 \pm 18$ \\
AMBG-2 & $104 \pm 16$ & $128 \pm 20$ \\
AMBG-3 & $105 \pm 14$ & $120 \pm 17$ \\
AMBG-4 & $107 \pm 16$ & $121 \pm 23$ \\
AMBG-5 & $106 \pm 16$ & $117 \pm 15$ \\
AMBG-6 & $108 \pm 17$ & $124 \pm 18$ \\
AMBG-7 & $108 \pm 15$ & $126 \pm 22$ \\
AMBG-8 & $106 \pm 14$ & $129 \pm 21$ \\
AMBG-9 & $108 \pm 15$ & $130 \pm 20$ \\
AMBG-10 & $106 \pm 14$ & $129 \pm 22$ \\
AMBG-11 & $110 \pm 17$ & $123 \pm 22$ \\
AMBG-12 & $107 \pm 14$ & $128 \pm 19$ \\
\hline
\end{tabular}

*AMBG in mean $\pm \mathrm{SD}$ in $\mathrm{mg} / \mathrm{dl}$

$\mathrm{n}=$ number of subjects

Significant difference between the groups by repeated measures general linear model $(P$ $<0.001)$. 
Table 4

Kilocalories Intake*

\begin{tabular}{cccc}
\hline & BF & FF & \\
\hline & $(n=12)$ & $(n=5)$ & $P$ \\
\cline { 2 - 4 } FW & $1724 \pm 551$ & $1781 \pm 489$ & NS \\
MW & $1970 \pm 537$ & $1641 \pm 395$ & $0.003 \uparrow$ \\
LW & $1969 \pm 501$ & $1917 \pm 500$ & NS \\
\hline
\end{tabular}

$* \mathrm{n}=$ number Subjects.

$\mathrm{FW}=$ First two weeks (Kcal).

$\mathrm{MW}=\mathrm{Mid}$ weeks $(\mathrm{Kcal})$

$L W=$ Last weeks $(\mathrm{Kcal})$.

$\mathrm{NS}=$ not significant

†Significantly difference by t-test. 
Table 5

Protein Intake

\begin{tabular}{cccc}
\hline & BF & FF & \\
\hline & $(n=12)$ & $(n=5)$ & $P$ \\
\cline { 2 - 4 } FW & $81 \pm 26$ & $87 \pm 25$ & NS \\
MW & $87 \pm 25$ & $79 \pm 29$ & NS \\
LW & $88 \pm 25$ & $87 \pm 26$ & NS \\
\hline
\end{tabular}

* Protein in grams

$\mathrm{n}=$ number of subjects

$\mathrm{NS}=$ not significant 
Table 6

Carbollydrate Intake*

\begin{tabular}{cccc}
\hline & BF & FF & \\
\hline & $(n=12)$ & $(n=5)$ & $P$ \\
\cline { 2 - 4 } FW & $228 \pm 80$ & $223 \pm 62$ & NS \\
MW & $262 \pm 69$ & $217 \pm 58$ & $0.002+$ \\
LW & $267 \pm 68$ & $247 \pm 66$ & NS \\
\hline
\end{tabular}

*Carbohydrate in grams.

$\mathrm{n}=$ number of subjects.

NS $=$ not significant

†significantly different by t-test. 


\section{Table 7}

Fat Intake*

\begin{tabular}{cccc}
\hline & BF & FF & \\
\hline & $(n=12)$ & $(n=5)$ & $P$ \\
\cline { 2 - 4 } FW & $56 \pm 26$ & $62 \pm 28$ & NS \\
MW & $67 \pm 29$ & $53 \pm 20$ & $0.02 \uparrow$ \\
LW & $65 \pm 26$ & $68 \pm 25$ & NS \\
\hline
\end{tabular}

*Fat in grams.

$n=$ number subject.

NS = not significant.

tsignificantly different by t-test. 
Table 8

Infiant's Weight*

\begin{tabular}{lcc}
\hline & BF & FF \\
\hline & $(n=13)$ & $(n=5)$ \\
\cline { 2 - 3 } Birth weight $(\mathrm{Kg})$ & $3.5 \pm 0.3$ & $3.3 \pm 0.4$ \\
6 weeks old weight $(\mathrm{Kg})$ & $5.1 \pm 0.5$ & $4.7 \pm 0.4$ \\
12 weeks old weight $(\mathrm{Kg})$ & $6.3 \pm 0.6+$ & $5.8 \pm 0.6$ \\
\hline
\end{tabular}

$*$ mean $\pm \mathrm{SD}$.

No significant differences between groups.

$\mathrm{n}=$ number of subjects.

tmean calculated with 11 infants. 
Table 9

Maternal Weight

\begin{tabular}{lcc}
\hline & BF & FF \\
\hline & $(n=13)$ & $(n=5)$ \\
\cline { 2 - 3 } Pre-pregnancy $(\mathrm{Kg})$ & $66 \pm 12.3$ & $68 \pm 4.5$ \\
6 weeks postpartum $(\mathrm{Kg})$ & $67 \pm 13$ & $67 \pm 4.1$ \\
12 weekspostpartum(Kg) & $68 \pm 13+$ & $68 \pm 4.5$ \\
\hline
\end{tabular}

*mean $\pm \mathrm{SD}$.

No significant difference between groups.

tmean calculated with 11 subjects. 
Table 10

Matermal BMI*

\begin{tabular}{lcc}
\hline & BF & FF \\
\hline & $(n=13)$ & $(n=5)$ \\
\cline { 2 - 3 } Pre-pregnancy BMI & $27.5 \pm 4.8$ & $27.9 \pm 1$ \\
6 weeks postpartum BMI & $27.4 \pm 4.7$ & $27.4 \pm 2$ \\
12 weekspostpartum BMI & $28 \pm 4.8 t$ & $27.6 \pm 1.9$ \\
\hline
\end{tabular}

$*$ mean $\pm \mathrm{SD}$.

No significant difference between the groups.

TMean calculated with 11 subjects. 
Figure 1

Capillary Plasma Blood Glucose

Date of Delivery and Fasting Blood Glucose

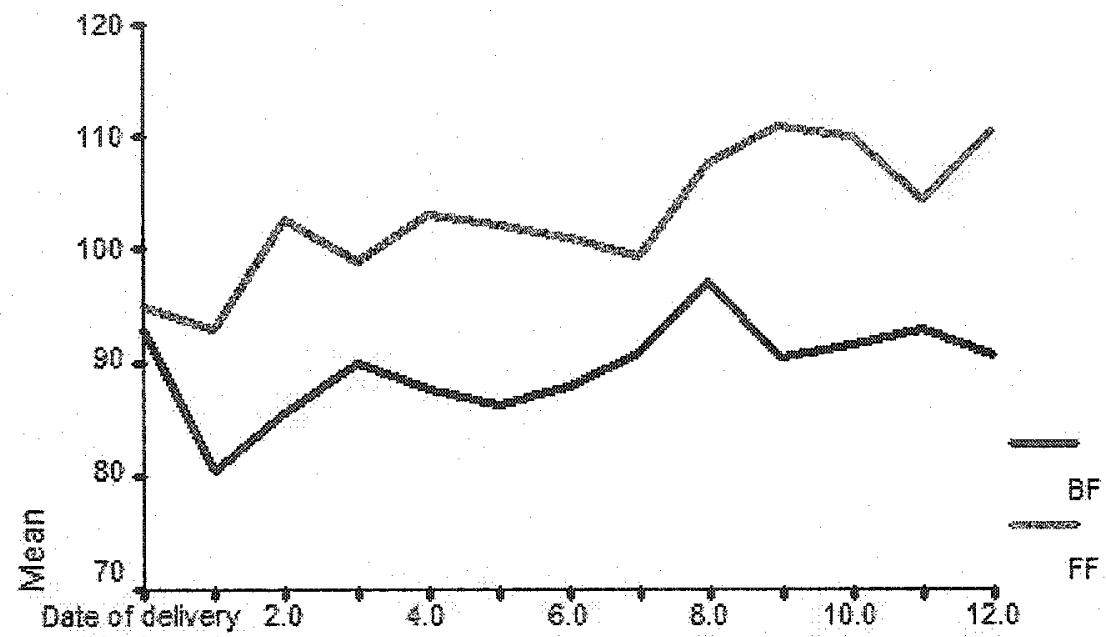

TIME $=$ Weeks 
Figure 1 Legend

Date of Delivery Blood Glucose and Fasting Plasma Glucose Concentrations Over the 12-Week Study Period

$\mathrm{BF}=$ Fasting blood glucose breastfeeding group.

$\mathrm{FF}=$ Fasting blood glucose formula-feeding group.

Time $=$ weeks.

Mean $=\mathrm{mg} / \mathrm{dl}$.

Blood glucose levels from date of delivery not significantly different

Significant difference between groups by repeated measurements general linear model $(P$ $<0.001)$.

Rate of increment $\mathrm{FF}=1.94 \mathrm{mg} / \mathrm{dl} /$ week; $P=0.002$ by linear regression.

Rate of increment $\mathrm{BF}=0.836 \mathrm{mg} / \mathrm{dl} /$ week; $P=0.008$ by linear regression. 
Figure 2

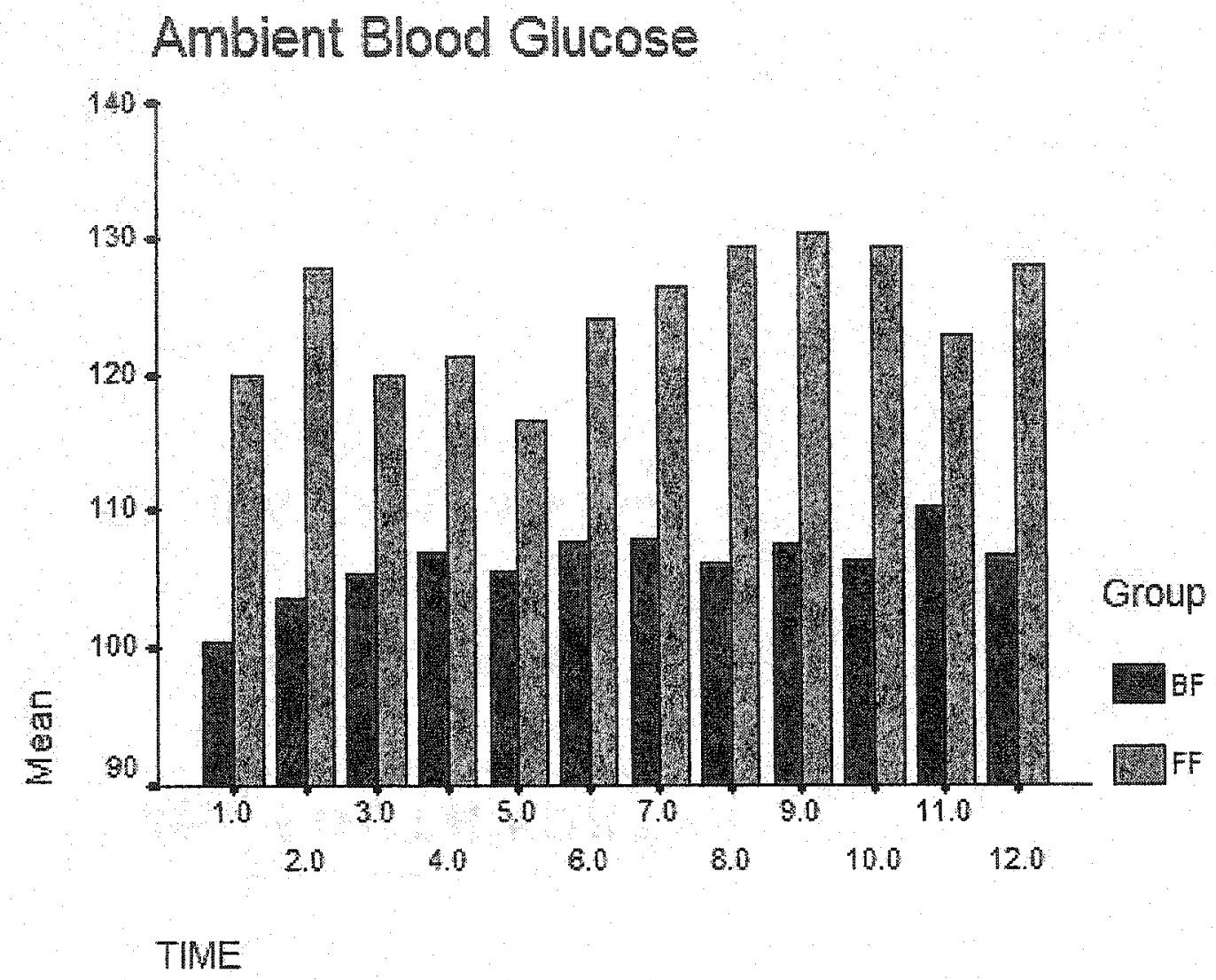




\section{Figure 2 legend}

Ambient Plasma Glucose Concentration Over the 12-Week Study Period

Mean in $\mathrm{mg} / \mathrm{dl}$

Time $=$ weeks.

Significantly different between groups by repeated measurements general linear model ( $P$ $<0.001)$.

The rate of increment of $\mathrm{AMBG}$ for the $\mathrm{BF}$ group was $0.497 \mathrm{mg} / \mathrm{dl} /$ week $(P=0.007)$ and for the FF group was 0.691 ( $P=0.06$ ) by linear regression. 
Figure 3

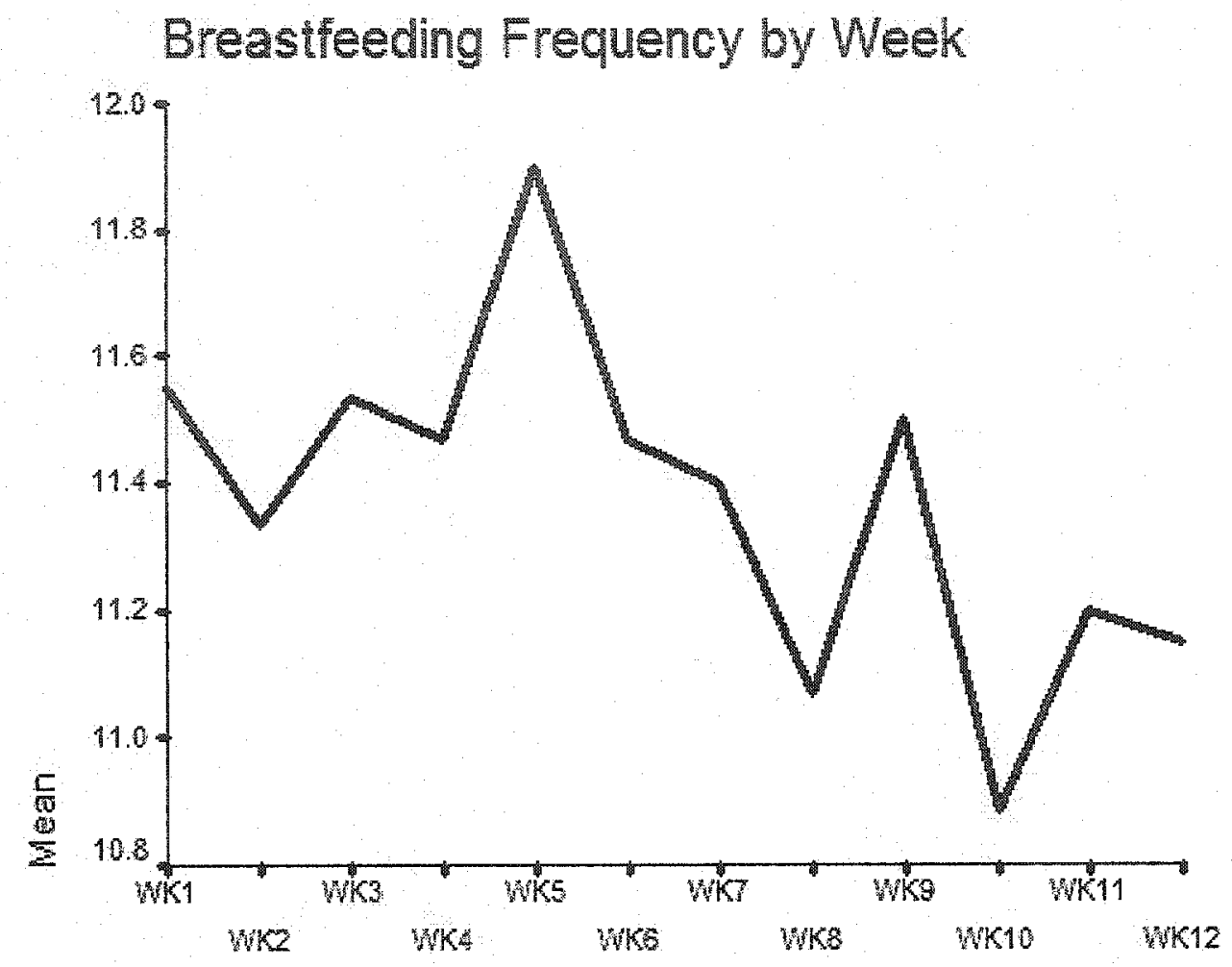




\section{Figure 3 Legend}

Frequency of Breastfeeding Over the 12-Week Study Period

Mean $=$ Frequency of breastfeeding

$\mathrm{WK}=$ Week 


\section{Figure 4}

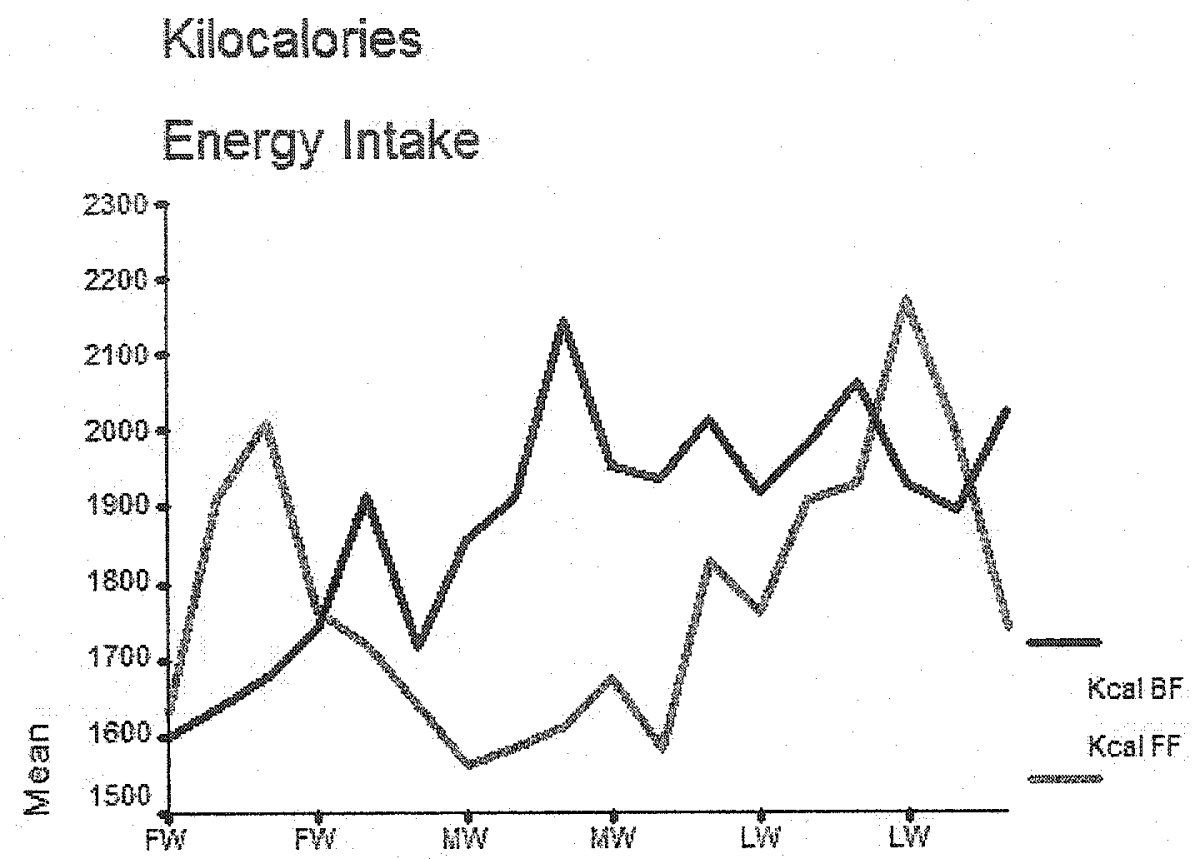

TIME 


\section{Figure 4 Legend}

Total Kilocalories Intake Over the 12-Week Study Period

Mean $=$ Kilocalories

Kcal BF increased significantly by linear regression $(P<0.001)$

Kcal FF changed significantly over time by general linear model $(P=0.006)$.

$F W=$ First two weeks not significant.

$\mathrm{MW}=\mathrm{Mid}$ weeks significantly different between groups by t-test $(P=0.003)$

$\mathrm{LW}=$ Last weeks not significant. 
Figure 5

Macronutrient Distribution

Breastfeeding

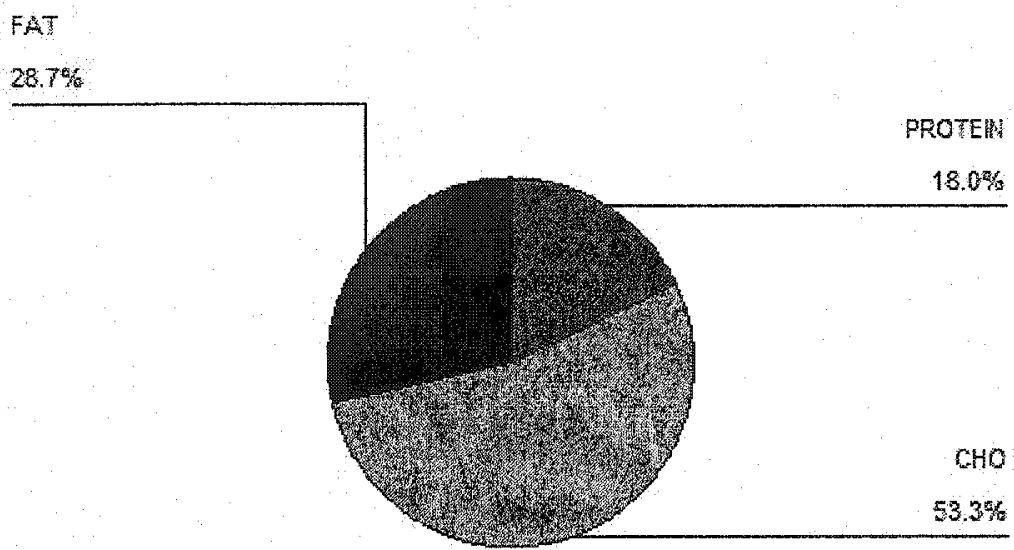

Macronutrient Distribution

Formula-feeding

FAT

$20.0 \%$

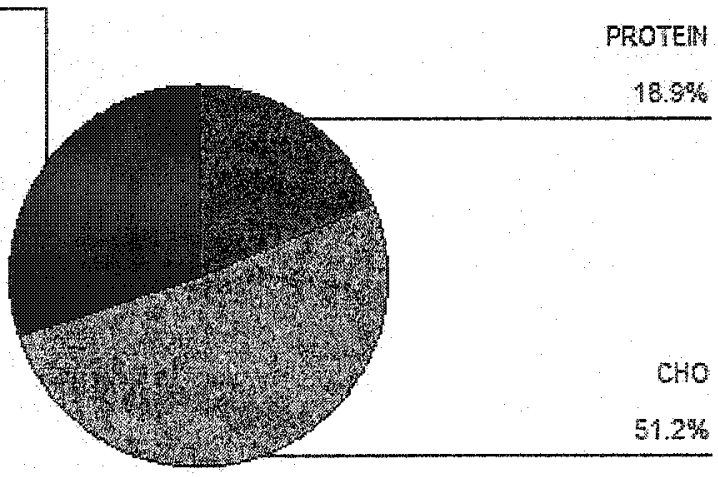


Figure 5 legend

Macronutrient Composition in the Breastfeeding (BF) and Formula Feeding (FF)

Groups Over the 12-Week Study Period

No significant differences between groups 


\section{References}

1. Harris MI: Diabetes in America: epidemiology and scope of the problem. Diabetes Care 21 (Suppl. 3): C11-C14, 1998

2. American Diabetes Association: Screening for type 2 diabetes. Diabetes Care 26: S21-\$24, 2003

3. Anderson JW: Nutritional management of diabetes mellitus. In Modern Nutrition in Health and Disease. $9^{\text {th }}$ ed. Shils,M.E., Olson, J.A., Shine,M. \& Ross,A.C, 1998 , p. $1365-1394$

4. Central Disease Control: Diabetes program, Statistics: Diabetes surveillance [article online], 1999. Available from http://www.cdc.org/diabetes/statistics/surv199/chap 1/intro.htm. Accessed 10 October 2001

5. Perez-Stable EJ, Mc Millen MM, HarrisMI, Jurez RZ, Knowler WC, Stern MP, Haynes SG: Self-reported diabetes in Mexican Americans: HHANES 1982-84. American Journal of Public Health 79: 770-772, 1989

6. Lunt H: Women and diabetes. Diabetes Med, 12: 1009-1016, 1996

7. Diabetes mellitus in Hispanic women [article online], 1998. Available from htt://www.4women.gov/owh/pub/factsheets/fshis-dia.htm. Accessed 20 October 2001

8. Kjos, S.L., Peters, R.K., Xiang, A., Henry, O., Montoro, M., \& Buchanan, T: Predicting future diabetes in Latina women with gestational diabetes. Diabetes 44: 586-591, 1995 
9. Domhorst, A., \& Rossi, M: Risks and prevention of type 2 diabetes in women with gestational diabetes. Diabetes Care 21 (Suppl. 2), 43B-49B, 1998

10. Montenen, J., Knekt, P., Jarvinen, R., Aromaa, A. and Reunanen, A: Whole-grain and fiber intake and the incidence of type 2 diabetes. The American Journal of Clinical Nutrition 77: 622-629, 2003

11. Tuomielehto, J., Lindstrom, J., Ericksson, J.G., Valle,T.T., Hamalainen, H., Ilanne-Parikka, P., et al: Prevention of type 2 diabetes mellitus by changes in lifestyle among subjects with impaired glucose tolerance. New England Journal of Medicine 344: 1343-1350, 2001

12. Brewer, M.M., Bates, M.R., and Vannoy, L.P: Postpartum changes in maternal weight and body fat depots in lactating vs nonlactating women. American Journal of Clinical Nutrition 49: 259-265, 1989

13. Dewey, K.G., Heining, M.J. \& Nommsen, L.A: Maternal weight-loss patterns during prolonged lactation. American Joumal of Clinical Nutrition 58: 162-166, 1993

14. Dietary Reference Intakes for Energy, Carbohydrate, Fiber, Fat, Fatty Acids, Cholesterol, Protein, and Amino Acids [article online], 2002. Available from http:/Www.iom.edu. Accessed 3 March 2003

15. Butte, N.F., Wong, W.W., and Hopkinson, J.M: Energy requirements of lactating women derived from doubly labeled water and milk energy output. Journal of Nutrition 131:53-58,2001 
16. Ferris, A.M., Dalidowitx, C.K., Ingardia, C.M., Reece, E. A., Fumia, F.D., Jensen, R.G., \& Allen, L.H: Lactation outcome in insulin-dependent diabetic women. Journal of the American Dietetic Association 88: 317-322, 1988

17. Kjos, S.L., Henry, O., Lee, R., Buchanan, T.A.\& Mishell, D.R: The effect of lactation on glucose and lipid metabolism in women with recent gestational diabetes. American Journal of Obstetrics and Gynecology 82: 451-455, 1993

18. Kjos, S.L., \& Buchanan, T.A: Gestational Diabetes Mellitus. The New England Journal of Medicine 341: 1749-1756, 1999

19. Kjos, S.L: Postpartum care of the women with diabetes. Clinical Obstetrics and Gynecology 43: 75-86, 2000

20. Illingworth, P.J., Jung,R.T., Howie, P.W., Leaslie, P., \& Isles, T.E: Diminution in energy expenditure during lactation. British Medical Journal: 292, 437-441, 1986

21. Burnol AF, Keturque A, Ferre P, Kande J, Girard: Increased insulin sensitivity and responsiveness during lactation in rats. The American Journal of Physiology: $252,537-541,1986$

22. Burnol AF, Ferre $P$, Keturque A, Girard: Effect of insulin on in vivo glucose utilization in individual tissues of anesthetized lactating rats. The American Journal of Physiology: 252, 183-188, 1986

23. Cowie AT, Forsyth IA, Hart IC: Hormonol control of lactation. Berlin: SpringerVerlag, 1980 
24. Shennan DB \& Peaker M: Transport of milk constituents by the mammary gland. Physiological Reviews: 80, 925-951, 2000

25. McGanity WJ, Dawson E.B, Van Hook JW: Matemal Nutrition. In Modern mutrition in health and disease. $9^{\text {th }}$ ed. Shils,M.E., Olson, J.A., Shine,M. \& Ross,A.C. Baltimore: Williams \& Wilkins; 1998. p. $811-838$

26. Metzger, B.E., Cho, N.H., Roston, S.M. \& Radvany, R: Pre-pregnancy weight and ante partum insulin secretion predict glucose tolerance five years after gestational diabetes mellitus. Diabetes Care: 16, 1598-1604, 1993

27. Buchanan, T.A., Metzger, B.E., Freinkel, N., \& Bergman, R.N: Insulin sensitivity and B-cell responsiveness to glucose during late pregnancy in lean and moderately obese women with normal glucose tolerance and mild gestational diabetes. American Journal of Obstetrics and Gynecology: 162, 1008-1014, 1990

28. Dornhorst, A., Bailey, P.C., Anyaoku, V., Elkelers, R.S., Johnston, D.G. \& Beard, R.W: Abnormalities of glucose tolerance following gestational diabetes. The Quarterly Journal of Medicine: 284, 1219-1228, 1990

29. Pallardo F., Herranz L., Garcia-Ingelmo,T., Grande C., Martin-Vaquero P., Janez. M., \& Gonzalez A: Early postpartum metabolic assessment in women with prior gestational diabetes. Diabetes Care: 22, 1053-1058, 1999

30. Ryan, E.A., Imes, S., Liu, D., McManus, R., Finegood, D. Polonsky, K.S. et al: Defects in insulin secretion and action in women with a history of gestational diabetes. Diabetes: 44, 506-512, 1995 
31. Dornhorst, A. \& Frost G: The potential for dietary intervention postpartum in women with gestational diabetes. Diabetes Care: $24,619-624,1997$

32. La Leche League International: The womanly art of breastfeeding. Schaumburg, Illinois. Press 1999

33. Basiotis PP, Welsh SO, Cronin FJ, Kelsay JL, Merzt WW: Number of days of food intake records required to estimate individual and group nutrient intakes with defined confidence. Journal of Nutrition: 117, 1638-1641, 1987

34. Butte NF, Garza C, Stuff JE, Smith EO, Nichols BL: Effect of maternal diet and body composition on lactation performance. American Journal of Clinical Nutrition, 39: 296-306, 1984

35. Mannin-Dalton C, Allen, LH: The effects of lactation on energy and protein consumption, postpartum weight change and body composition of well nourished North American women. Nutrition Research, 3: 293-308, 1983

36. Durnin JVGA: Food consumption and energy balance during pregnancy and lactation. In Maternal Nutrition during Pregnancy and Lactation New Guinea. Aebi HB, Whitehead RG Berne: Hans Huber, 1980 p. 86-95

37. Prentice AM, Whitehead RG, Roberts SB, Paul AA: Long-term energy balance in child-bearing Gambian women. American Journal of Clinical Nutrition, 34: 27902799: 1981

38. Schutz Y, Lechting A, Bradfield RB: Energy expenditures and food of lactating women in Guatemala. American Journal of Clinical Nutrition, 33: 892-902, 1980 
CHAPTER III

SUMMARY AND RECOMMENDATIONS 


\section{Summary and Recommendations}

Breastfeeding may assist Latina women with gestational diabetes in improving blood glucose regulation and slowing the progression of the development to type 2 diabetes. It has been suggested that a positive effect on blood glucose regulation will occur if a woman with a previous history of gestational diabetes chooses to breastfeed. The data from the present study clearly indicate that breastfeeding improves blood glucose regulation in overweight Latina women with a history of gestational diabetes. Specifically, the results of this study demonstrated that both fasting blood glucose and ambient blood glucose levels were significantly lower throughout the 12 weeks of the study in the lactating women than the non-lactating women. The levels of fasting blood glucose and ambient blood glucose were increasing as the time progressed in both groups. However, the rate of increase was slower in the lactating women than the nonlactating women. Other studies have indicated that 60 to $80 \%$ of women may develop type 2 diabetes within five years after experiencing gestational diabetes mellitus. The increase of blood glucose levels noted in this study implies that the women who participated in the study may eventually develop type 2 diabetes. The fact that breastfeeding was able to slow down the rate of increment of glucose levels suggests that breastfeeding may provide protection in overweight/obese women with a previous history of gestational diabetes by slowing the progression of the development to type 2 diabetes. Although breastfeeding may assist women in slowing the progression to type 2 diabetes, there are other risks that they encounter such as diet; overweight/obesity and the lack of physical activity that will also influence this progression. Health care providers should 
educate women with gestational diabetes during pregnancy on healthy lifestyle habits including a discussion in regards to their choice of method of feeding their babies in order to reduce the risk of developing type 2 diabetes.

Another important observation of the present study relates to the total energy and macronutrient intake. As expected, the lactating women were consuming a higher caloric intake than the non-lactating women. However, the lactating women did not consume the dietary reference intake recommendations for the kilocalories intake during lactation. Nevertheless, the infants that were breastfed gained the recommended weight in spite of this and infant weight gain was indistinguishable from that observed among the formula fed infants. Moreover, most of the lactating women were overweight and consuming calories above what was actually needed for milk synthesis, which would certainly contribute to further weight gain. The women in the present study were able to provide adequate milk to support normal infant growth and development and gained weight regardless of the fact that hey were consuming much less than the recommended caloric intake. Thus, the recommended dietary intakes for lactation may be set too high for an overweight or obese woman with gestational diabetes, especially if she is trying to lose weight. When counseling obese women that lactation may help facilitate weight loss following delivery, health care providers need to educate these women that the dietary recommendations for calories needed during lactation were developed for active women of normal body mass index and that overweight women may need to consume a lower caloric intake than recommended. It has been shown that by consuming $1800 \mathrm{kcal} / \mathrm{day}$ overweight women can loose weight and produce enough milk to sustain the growth of 
their infants. However, eating a restricted caloric diet may be detrimental to the amounts of micronutrient intake.

The health, nutritional, and psychological benefits of breastfeeding to the mother and to the infant are widely acknowledged. Moreover, in recognition of these known benefits, breastfeeding is the infant-feeding method recommended by the American Academy of Pediatrics, the American Public Health Association, and the American Dietetic Association for the first four to six months of life. At least part of the significance of the present study is that it provides important information and the impetus for health care providers to educate and encourage women at risk for the development of obesity and/or diabetes important information on the potential health benefits of breastfeeding. Women who decided to breastfeed needed a great amount of support to overcome breastfeeding difficulties and successfully breastfeed their infants. During the home visits, the lactation educator worked with perseverance with the mothers to solve common but at times challenging struggles. The most difficult times were the first 3 weeks postpartum where positioning, latching, question about frequent feedings and sleepy babies due to jaundice were the most common and simple problems, yet critical for a woman to succeed with breastfeeding. Another problem was the uncertainty of the mothers about not producing enough milk. However, due to the consistency of home visits, mothers were able to overcome that fear. Therefore, public health systems should recognize the importance of highly implementing home visiting programs that assist mothers with breastfeeding support. 
Even though this study had a relatively small sample size, we were able to demonstrate significant benefits in this patient population. Future studies are needed using a larger sample size that include other high-risk populations. The women from this study were engaged and interested in the study, which contributed to its success. There were two main driving factors of why this study had an increased receptiveness. First, the women were highly interested in knowing what would happen to their blood glucose after delivery. Usually, women with gestational diabetes after delivery have only one appointment at six weeks postpartum, but many of them miss their appointment. This is due to the barriers that these women encounter such as language and transportation or that clinics simply do not follow up on missed appointments. Therefore, the idea of home visiting by a health care provider and continuing checking of their blood sugars was acceptable to them. Second, the women felt comfortable and satisfied with the home visits especially when the nutritionist was competent, fluent in their native language, and culturally sensitive.

In conclusion, health care systems should implement home visiting programs where women who experience gestational diabetes can obtain assistance with breastfeeding. This program should also educate women on the importance of healthy eating habits and physical activity to acquire a healthy weight and reduce the risk of developing type 2 diabetes. 


\section{References}

American Diabetes Association (2003). Screening for type 2 diabetes. Diabetes Care, 26, S21-S24.

American Diabetes Association (2003). Evidence-based nutrition principles and recommendations for the treatment and prevention of diabetes and related complications. Diabetes Care, 26, S51-S61.

American Diabetes Association (2003). Gestational Diabetes Mellitus. Diabetes Care,26, S103-S105.

Anderson, J.W. (1998). Nutritional management of diabetes mellitus. In Shils,M.E., Olson, J.A., Shine,M. \& Ross,A.C. $\left(9^{\text {th }}\right.$ ed. $)$, Modern nutrition in health and disease (1365-1394). Baltimore: Williams \& Wilkins.

Berkowitz, G.S., Lapinski, R.H., Wein, R., \& Lee, D. (1991). Race/ethnicity and other risk factors for gestational diabetes. American Journal of Epidemiology, 135, 965973.

Brewer, M.M., Bates, M.R., and Vannoy, L.P. (1989). Postpartum changes in maternal weight and body fat depots in lactating vs nonlactating women. American Journal of Clinical Nutrition, 49, 259-265.

Buchanan, T.A., Metzger, B.E., Freinkel, N., \& Bergman, R.N. (1990). Insulin sensitivity and B-cell responsiveness to glucose during late pregnancy in lean and moderately obese women with normal glucose tolerance and mild gestational diabetes. American Journal of Obstetrics and Gynecology, 162, 1008-1014. 
Butte, N.F., Garza, C., Stuff, J.E., Smith, E.O. and Nichols, B.L. (1984). Effect of matemal diet and body composition on lactation performance. American Joumal of Clinical Nutrition, 39, 296-306.

Butte, N.F., Wong, W.W., and Hopkinson, J.M. (2001). Energy requirements of lactating women derived from doubly labeled water and milk energy output. Journal of Nutrition, 131, 53-58.

Catalano, P.M., Tyzbir, E.D., Roman, N.M., Amini, S.B., and Sims, E.H. (1991). Longitudinal changes in insulin release and insulin resistance in non-obese pregnant women. American Journal of Obstetrics and Gynecology, 165, 16671672 .

Central Disease Control. (1999). Diabetes program. Statistics. Diabetes surveillance (chap. 1).Retrieved October 10, 2001, from http:/www.cdc.org/diabetes/statistics/surv199/chap1/intro.htm

Davies, H.A., Clark, J.D.A., Dalton, K.J. \& Edwards, O.M. (1989). Insulin requirements of diabetic women who breastfeed. British Medical Journal, 298, 1357-1358.

Dewey, K.G., Heining, M.J. \& Nommsen, L.A. (1993). Maternal weight-loss patterns during prolonged lactation. American Journal of Clinical Nutrition, 58, 162-166. Diabetes Prevention Program Group (2002). Reduction in the incidence of type 2 diabetes with lifestyle interventions or metformin. The New England Joumal of Medicine, $346,393-403$. 
Dormhorst, A., Bailey, P.C., Anyaoku, V., Elkelers, R.S., Johnston, D.G. \& Beard, R.W. (1990). Abnormalities of glucose tolerance following gestational diabetes. The Quarterly Journal of Medicine, 284, 1219-1228.

Dornhorst, A. \& Frost G. (1997). The potential for dietary intervention postpartum in women with gestational diabetes. Diabetes Care, 24, 619-624.

Domhorst, A., Paterson, C.M., Nicholls, J.S.D., Wadsworth, J., Chiu, D.C., Elkeles, R.S. et al. (1992). High prevelance of gestational diabetes in women from ethnic minorities groups. Diabetic Medicine, 9, 820-825.

Dornhorst, A., \& Rossi, M. (1998). Risks and prevention of type 2 diabetes in women with gestational diabetes. Diabetes Care. 21(Suppl. 2), 43B-49B.

Durnin, J.V.G.A. (1980). Food consumption and energy balance during pregnancy and lactation in New Guinea. In Aebi H.B., Whitehead, R.G. Maternal Nutrition during Pregnancy and Lactation (p.p. 86-95). Berne: Hans Huber.

Eckhardt, K.W. \& Hendershot, G.E. (1984). Analysis of the reversal in breastfeeding trends in the early 1970s. Public Health Reports, 99, 410-415.

Eriksson, J., Taimela, S., \& Koivisto, V.A. (1997). Exercise and the metabolic syndrome. Diabetologia, 40, 125-135.

Ferris, A.M., Dalidowitx, C.K., Ingardia, C.M., Reece, E. A., Fumia, F.D., Jensen, R.G., \& Allen, L.H. (1988). Lactation outcome in insulin-dependent diabetic women. Joumal of the American Dietetic Association, 88, 317-322. 
Feskens, E.J.M., Stengard, J., Virtanen, S.M., Pekkanen, J., Rasanen, L., Nissinen, A. et al. (1995). Dietary factors determiningdiabetes and impaired glucose tolerance. Diabetes care, $18,1104-1112$.

Fulton-Kehoe, D., Hamman, R.F., Baxter, J., \& Marshall, J. (2001). A case control study of physical activity and non-insulin dependent diabetes mellitus: the San Luis valley diabetes study. Annals of Epidemiology, 11, 320-327.

Gerstein, H.C. (1994). Cow's milk exposure and type 1 diabetes mellitus: a critical overview of the clinical literature. Diabetes care, 17, 13-19.

Gutteridge, I.F. (1999). Diabetes mellitus: a brief history, epidemiology, definition and classification. Clinical and Experimental Optometry, 82, 102-106.

Janke, J.R. (1993). The incidence, benefits and variables associated with breastfeeding: Implications for practice. Nurse Practitioner, 18,22-32.

Kjos, S.L. (2000). Postpartum care of the women with diabetes. Clinical Obstetrics and Gynecology, 43, 75-86.

Kjos, S.L., \& Buchanan, T.A (1999). Gestational Diabetes Mellitus. The New England Journal of Medicine, 341, 1749-1756.

Kjos, S.L., Henry, O., Lee, R., Buchanan, T.A.\& Mishell, D.R. (1993). The effect of lactation on glucose and lipid metabolism in women with recent gestational diabetes. American Journal of Obstetrics and Gynecology, 82, 451-455.

Kjos, S.L., Peters, R.K., Xiang, A., Henry, O., Montoro, M., \& Buchanan, T. (1995). Predicting future diabetes in Latina women with gestational diabetes. Diabetes, $44,586-591$. 
Healthy People 2010 (1999). Healthy people objectives: Draft. Retrieved January 19,1999 from http/web.health.gov/healthypeople/2010draftobject.htm

Henry, O.A., \& Beischer, N.A. (1991). Long-term implication of gestational diabetes to the mother. Clinical Obstetrics and Gynecology, 5, 461-484.

Hollenbeck C.B., Haskell W., Rosenthal M., \& Reaven G.M. (1984) Effect of habitual physical activity on regulation of insulin-stimulated glucose disposal in older males. I Am Geriatr Soc 33:273-277.

Holte, J., Bergh, T., Berne, C., Wide, L. \& Lithell, H. (1995). Restored insulin sensitivity but persistently increased early insulin secretion after weight loss in obese women with polycystic ovary syndrome. Joumal of Clinical Endocrinology Metabolism, $80,2586-2593$

Illingworth, P.J., Jung,R.T., Howie, P.W., Leaslie, P., \& Isles, T.E. (1986). Diminution in energy expenditure during lactation. British Medical Journal, 292, 437-441.

Institute of Medicine (2002). Dietary Reference Intakes for Energy, Carbohydrate, Fiber, Fat, Fatty Acids, Cholesterol, Protein, and Amino Acids. Retrieved March 3, 2003 from http://www.iom.edu

Lawrence, R.A. \& Lawrence, R.M. (1999). In Breastfeeding: A guide for the medical profession ( $5^{\text {th }} \mathrm{ed}$.). Saint Louis: Mosby

Lehninger, A.L., Nelson, D.L., \& Cox, M.M.(1993). Principals of Biochemestry $\left(2^{\text {nd }}\right.$ ed.). New York: Worth Publishres. 
Long, S.D. O'Brien, K., MacDonal, K.G., Leggett, N., Swanson, M.S. Pories, W.I. et al. (1994). Weight loss in severely obese subjects prevents the progression of impaired glucose tolerance to type 2 diabetes : a longitudinal interventional study. Diabetes Care, $17,372-375$.

Lunt,H. (1996). Women and diabetes. Diabetes Med, 12,1009-1016.

Mannin-Dalton, C., Allen, L.H. (1983). The effects of lactation on energy and protein consumption, postpartum weight change and body composition of well nourish North American women. Nutrition Research, 3, 293-308.

Manson, J.E., Rimm, E.B., Stamfer, M.J., Colditz, G.A., Willet, W.C., Krolewski, B.R. et al. (1991). Physical activity and incidence of non-insulin dependent diabetes mellitus in women. Lancet, 338, 774-778.

Manson, J.E., Spelberg, A. (1994). Primary prevention of non-insulin dependent diabetes mellitus. American Journal of Preventive Medicine, 10, 172-184.

Marshall, J.A., Bessesen, D.H. \& Hamman, R.F. (1997). High saturated fat and low starch and fiber are associated with hyperinsulinemia in a non-diabetic population: San Luis Valley Study. Diabetologia, 40, 430-438.

Marshall, J.A., Hamman, R.F. \& Baxter, J. (1991). High fat, low carbohydrate diet and the etiology of non-insulin-dependent diabetes: San Luis Valley Study. American Journal of Epidemiology, 134, 590-603.

Mayers-Davies, E.J., Monaco, J.H., Hoen, H.M., Carmichael, S., Vitolins, M.Z., Rewers, J. et al. (1997). Dietary fat and insulin sensitivity in a triethnic population: the role 
of obesity. The insulin resistance atherosclerosis study. American Journal of Clinical Nutrition, 65, 79-87.

Metzger, B.E., Bybee, D.E., Freinkel, N., Phelps, R.L., Radvany, R.M. \& Vasirub, N. (1985). Gestational diabetes mellitus: correlations between the phenotypic and genotypic characteristics of the mother and abnormal glucose tolerance during the first year postpartum. Diabetes, 34, S111-S115.

Metzger, B.E., Cho, N.H., Roston, S.M. \& Radvany, R. (1993). Pre-pregnancy weight and ante partum insulin secretion predict glucose tolerance five years after gestational diabetes mellitus. Diabetes Care, 16, 1598-1604.

McGanity, W.J., Dawson, E.B. \& Van Hook, J.W (1998). Maternal Nutrition. In Shils,M.E., Olson, J.A., Shine,M. \& Ross,A.C. $\left(9^{\text {th }}\right.$ ed.), Modern nutrition in health and disease (811-838). Baltimore: Williams \& Wilkins.

Montenen, J., Knekt, P., Jarvinen, R., Aromaa, A. and Reunanen, A. (2003). Whole-grain and fiber intake and the incidence of type 2 diabetes. The American Journal of Clinical Nutrition, 77, 622-629.

Moses, R.G. (1996). The recurrence rate of gestational diabetes in subsequent pregnancies. Diabetes Care, 19, 1349-1356.

Moses, R.G., Shand, J.L., \& Tapsell, L.C. (1997). The recurrence of gestational diabetes mellitus: could dietary differences in fat intake be an explanation?. Diabetes Care, 20, 1647-1650. 
Murtaugh, M.A., Ferris, A.M., Capacchione, C.M., \& Reece, A. (1998). Energy intake and glycemia in lactating women with typel diabetes. Journal of the American Dietetic Association, $98,642-648$.

Office on women's Health (1998). Diabetes mellitus in hispanic women. Retrieved October 20, 2001, from htt:/www.4women.gov/owh/pub/factsheets/fshis-dia.htm

Ohlson, L.O., Larsson, B., Svardsudd, K., Welin, L., Erikson, H., Wilhelmsen, L. et al. (1985). The influence of body fat distribution on the incidence of diabetes mellitus. Diabetes, 34, 1055-1058.

Pallardo F., Herranz L., Garcia-Ingelmo,T., Grande C., Martin-Vaquero P., Janez M., \& Gonzalez A. (1999). Early postpartum metabolic assessment in women with prior gestational diabetes. Diabetes Care, 22, 1053-1058.

Perez-Stable,E.J., Mc Millen,M.M., Harris,M.I., Jurez, R.Z., Knowler,W.C., Stern,M.P. \& Haynes,S.G.(1989). Self-reported diabetes in Mexican Americans: HHANES 1982-84. American Journal of Public Health, 79, 770-772.

Peters, R.K., Kjos, S.L., Xiang, A. \& Buchanan, T.A. (1996). Long-term diabetogenic effect of single pregnancy in women with previous gestational diabetes mellitus. Lancet, $347,227-230$.

Philipson, E.H., \& Super, D.M. (1989). Gestational diabetes mellitus: Does it occur in subsequent pregnancy?. American Joumal of Obstetrics and Gynecology, 160 , $1324-1331$. 
Prentice, A.M., Whitehead, R.G., Roberts, S.B. and Paul. A.A. (1981). Long-term energy balance in child-bearing Gambian women. American Joumal of Clinical Nutrition, 34, 2790-2799.

Raaij, J.M., Schonk, C.M., Vermaat-Miedema, S.H., Peek, M.E. and Hautvast, J.G. (1991). Energy cost of lactation, and energy balances of well-nourished Dutch lactating women: reappraisal of the extra energy requirements of lactation. The American Journal of Clinical Nutrition, 53, 612-619.

Ross Products Division of Abbott Laboratories (1999). Mother's survey updated breastfeeding trend through 1998. Columbus, Ohio.

Ryan, E.A., Imes, S., Liu, D., McManus, R., Finegood, D. Polonsky, K.S. et al. (1995). Defects in insulin secretion and action in women with a history of gestational diabetes. Diabetes, 44, 506-512.

Ryan, E.A., O’Sullivan, M.J., \& Skyler, J.S. (1985). Insulin action during pregnancy: studies with the euglycemic clamp technique. Diabetes, $34,380-389$.

Saunders, S., Carrol, J. and Johnson, C. (2 ${ }^{\text {nd }}$ ed.). (1998). Breastfeeding: A problem solving manual. Amityville, N. Y: Essential Medical Information Systems Inc.

Schutz, Y., Lechting, A., and Bradfield, R.B. (1980). Energy expenditures and food of lactating women in Guatemala. American Joumal of Clinical Nutrition, 33, 892902. 
The Expert Committee on the Diagnosis and Classification of Diabetes Mellitus (2003). Report of the expert committee on the diagnosis and classification of diabetes mellitus. Diabetes Care, 26, \$5-\$20.

The Food and Agriculture Organization, World Health Organization and United Nations University (1985). Energy and protein requirements. World Health Organization, Geneva, Switzerland, technical report series, No. 724, 1-67.

Tuomielehto, J., Lindstrom, J., Ericksson, J.G., Valle,T.T., Hamalainen, H., IlanneParikka, P., et al. (2001). Prevention of type 2 diabetes mellitus by changes in lifestyle among subjects with impaired glucose tolerance. New England Journal of Medicine.344, 1343-1350.

U.S. Department of agriculture. Continuing Survey of Food Intakes by Individuals (1994$1996,1998)$

Varrala, O. (1999). Cow's milk formula feeding induces primary immunization to insulin in infant at genetic risk for type 1 diabetes. Diabetes, 48, 1389-1394.

Whichelow, M.J., Doddridge, M.C. (1983). Lactation in Diabetic Women. British Medical Journal, 287, 649-650.

Yang,J.Q., Xu,Y.H., \& Gai,M.Y.(1994). Breastfeeding in reducing regular insulin requirement in postpartum for insulin dependent diabetes mellitus and gestational diabetes mellitus. Zhoghua Fu Chan Ke Za Zhi.,29,135-188. 


\section{Appendix A}

\section{Collaborative Letter}

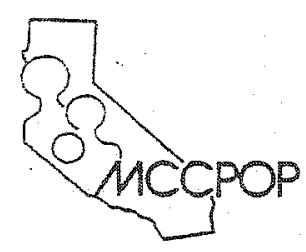

MD-COASTAL CALIFOHNA PERINATAL OUTREACH PROGRAM

Charles $B$, and Ann $b$ Johnson Center for Pregnancy and Newbon Services

750 Welch Foad, Sulte 224, Palo Alto, California 94004

Phon (650) 723-5763 * Fax (650) 723-2829 - Enaj: daychingstanordedu

April 3, 2002

Clarie Hollenbeck, $\mathrm{PLD}$

Deparment of Nutrition and Food Science

Graduate Advisor

San Jose State University

One Washington Square

San Jose, CA 95192-0058

Dear Dr. Hollenbeck:

I have reviewed Manuel Villacosta"s proposed graduate project entitled "Effects of Breastfeeding on Blood Glucose Regulation Among Overweight/Obese Latino Women with a History of Gestational Diabetes." I would be pleased to collaborate with you and Manuel on his graduate project at San Jose State University. Manuel has our permission to recruit individuals for his research protocol from our patient population and do not anticipate a problem.in obtaining the desired number of individuais. He will need to ger Institutional Review Board approval from San Jose State University before he can begin recruiting individuals.

I look forward to collaborating with you on this interesting protocol.

Sincerely,

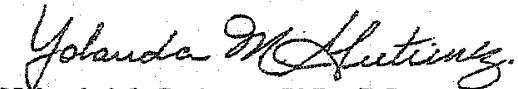

Yolanda M. Guierrez, PhD., RD.

Regional Perinatal Nutrition Consultant Stanford University

Associate Clinical Professor, UCSF 


\section{Appendix B}

\section{Certification of Human Subjects Approval: Stanford University}

David M. Gaba, MD.

STANFORD UNIVERSITY

Stanford, Califorria 94305-5401

CHAIR PANEL ON MEDICAL HUMAN SUBJECTS

(650) $725-5873$

co Adnimistrative Panels Office

\section{Certification of Human Subjects Approval}

Date: July 9, 2002

To: Il-Sayed, Y.M.D., Department Of Gynecology and Obstetrics

From: David M. Gaba, M.D., Chairman, Administrative Panel on Human Subjects in Medical Research

Protocol Titie:

Efrects of Breastfeeding on Weight and Blood Glucose Regulation in Overweight Lacino Women with Gestational Diabetes Mellirus.(Approval inchudes informed consent 7/9/02)

Protocol iD:

78285

IRB Number: 350 (Panel 3)

The Panel apjoroved human subjects involvement in your research project on July 9, 2002. If there is a contract involved, it must be signed before subject recruitment and enroliment.

The expiration date of this approval is July 8,2003 . If this project is to continue beyond that date, please submil an updated proposal in advance for the Penel's re-approval. If this proposal is used in conjunstion with any other human experimentation or if it is modified in any way, it must be re-approved for these special circumstanees. Note that the following should be promplly reporied to the panel: i) all serious adverse everits, occurring here or at other institutions, regardless of whether or not they are thought to be study related, 2) any unanticipated problems, and/or 3) any injuries to subjects enrolled here.

All continuing projects and activities must be reviewed and re-approved at least annually by the Panel. Panel approval of any project is for a maximum period of one year. It is the responsibility of the investigator to resubmit the project to the Panel for continuing review.

Please remenber that all data includisg all signed consent form documents must be retsined for a minimum of three years past the completion of this research. Additional requirements may be imposed by your funding agency, your department, or other entities. (Polioy on Retention of and Access to Research Data, Research Policy Handbook, www.stantord.edw/dept/Dolirph/2-10.hmol).

This instirution is in compliance with requirements of protection of human subjects ( 45 CFR 46 and 21 CFR 56).

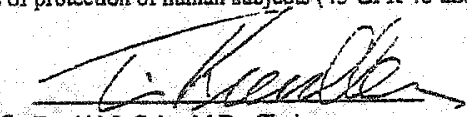

q2David M. Gabs, M.D., Chieirman

\section{Approval Peried: $\quad 7 / 9 / 2002$ through 7/8/2003 \\ Review Type: Expedited - NEW}

Fundag:

Coop Inst: San Jose State University

Asssirame Niumber FWA00000933 (IPCH); FWA00000935 (SU)

TRS Number: $\quad 350$ (Panel 3)

Expedited Under Para: 2 


\section{Appendix C}

\section{Institutional Review Board Approval: San Jose State University}

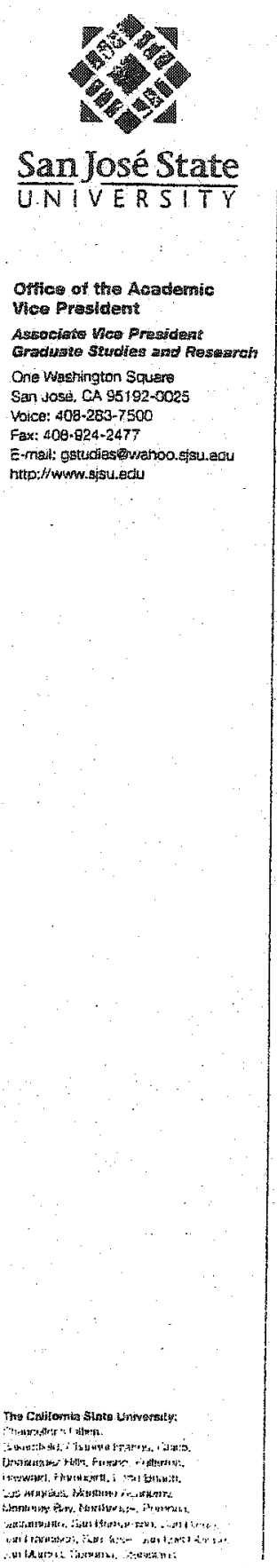

To: Manuel Villacorta

$393920^{\text {th }}$ Street, Apt. 10

San Francisco, CA 94114

From: Nabil Ibrahim, of

Date: June 24,2002

The Human Subjects-Institutional Review Board has given conditional approval to use human subjects in the study entitled:

"Effects of Breastfeeding on Blood Glucose Regulation among

Overweight/Obese Latino Women with History of Gestational Diabetes."

The Board requires that the following conditions are met and a copv of the requested materials submitted to the HS-IRB:

1. Please forward an approved copy (per Stanford's IRB) of the finalized consent form for our review. Please include both English and Spanish versions of the form. The text will be checked for conformity with SISU policy.

2. When obtained, please forward a copy of the IRB approval letter or. notice from the IRB at Stanford for our records.

You may proceed with the portion of your project outlined as requiring additional information only after receiving full approval status from the HS-IRB at San Jose State University.

If you have any questions or need assistance, please contact Eileen Fortin, HS-IRB Coordinator at 408-924-2479 


\section{Appendix D}

\section{Small Research Grant Award Letter}

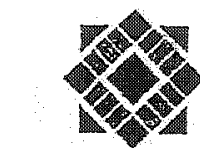

SanJosé State

UNIVERSITY

College of Appliad Sclente

and Ants

Ofince of the Desen

One Wasthrgatan Square

San Jeso, CA 95152-5049
Vosce:

$\begin{array}{ll}\text { Voice: } & 408-924-2600 \\ \text { Fax: } & 408-924-2509\end{array}$

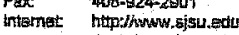

depasicasa'

Dean:

Dr. Michast M. Ego
March 15, 2002

Menuel Villacorta

393920 th Stret \#10

San Franciseo, CA:

Dear Manuel:

Congratulations! Upon the recommendation of the Research and Faculty Development Committee of the College of Applied Sciences and Arts, I am pleased to inform you that your research proposal has been approved for funding of $\$ 500$.

Attrched is a Proposal for New Account forn. If you are a faculty applicant, please sign your mane under "Authorized Signatures for Expenditure". If you are a student applicant, please have your faculty advisor sign under "Authorized Signatures for Expenditure". Upon receipt of the signed Proposal for New. Account form from you, I will authorize the SISU Foundation to establish an award account for you. Please submit this signed form to Bonnie Beckler, no later than Friday, April 5, 2002.

Foundation will be in touch with you with an assigned account number. At that point you may contact then for information regarding expending your award finds. If you have a faculty advisor, he/she will be the insividual with authority to authorize and sign for expenditures. Be sure to keep receipts for reimbursement for the expendiaures incurred on your project. All funds must be spent by September 30. 2003.

At this time, let me remind you that the guidelines and procedures of the Human Subjects Review Conmittee must be followed if applicable, and any "sotware" or other reusable materials purchased under the snall grant proposal program should be made available to other researchers in the College, should they need them.

Additionally I am nequesting that each recipient of the small grant submit a final writter report of their funded project to the College Research and Faculty Develogment Committee bv December 15, 2003. Your faculty advisor can assist you with the report.

Student winners of the College Small Research Grant for 2002-2003 will be recognized for their awards by the Dean's Office/Alumni Association at its annual awards reception, May 6,2002, from 5:00 p.m. - 7:00 p.m. in the Barrett Ballroom, Stadent Unier. Please RSVP to 9242900 by Monday, April 22, 2002.

I am pleased to support the researoh efforts of sudents and faculty in our College. If you have ary questions, please don't hesitate to call my office.

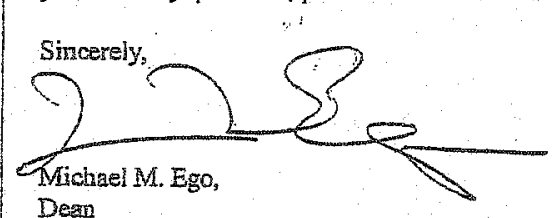

Dearn

cc: Natalie Harding, Resource Analyst 
Appendix E

Circle of Friends Award letter

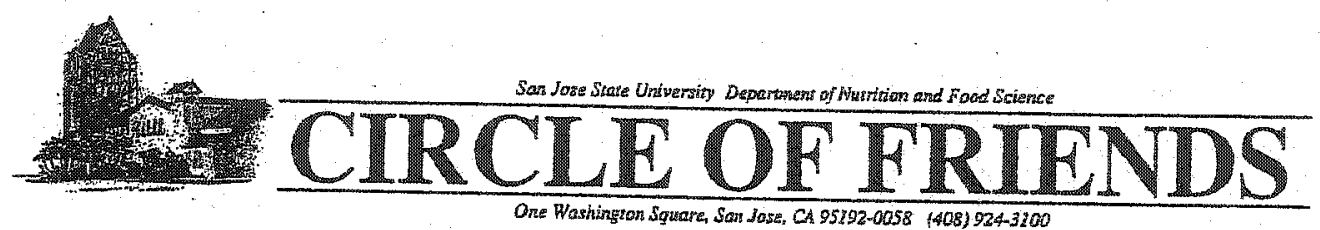

May 14, 2002

Manuel Villacorta

3939 20th Street, Apt. 10

San Francisco, CA 94114

Dear Manuel:

We are delighted to inform you that your research proposal, Effects of Breastfeeding on Blood Glucose Regulation in Type 2 Diabetic Latino Women, has been selected by the Student Research Assistance Committee to receive the Circle of Friends Research Assistance Award in the amount of $\$ 500$. You will be notified when this award check is available.

The award amount is designed to angment the cost of research related supplies. Therefore, as a condition of receiving this award, you are required to submit, upon completion of your study, a one page final report. This report should explain how the items purchased with the Research Assistance Award contributed to your findings.

Please accept our admiration for this outstanding research proposal and congratulations on receiving this award.

Sincerely,

$\angle 2 \frac{2}{20}$

Caroline Fee, MA.

Director, Circle of Friends

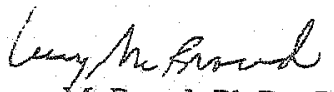

Lucy McProud, Ph.D., R.D.

Chair, Department of Nutrition and Food Science 


\section{Appendix F}

\section{Informed Consent: English}

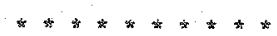

\section{INFORMED CONSENT}

Are you participating in any other research studies? yes no

Title of Protocol: Effects of Breastiesdina on Blood Glucose Levels Among Overweiaht Latino Women with a History of Gestational Diabetes.

Meeting Date 07116102

You are invited to participate in a research study investigating the effects of breastfeeding on blood sugar levels in Latina women with a history of diabetes during pregnancy. We hope to learn more about the effects of breastfeeding on body weight, and the levels of giucose (sugar) in your blood. You were selected as a possible particioant in this study because you are pregnant Latino woman who has been diagnosed with diabetes during this pregnancy.

Your participation in this study is entirely voluntary. If you decide to participate, you will be asked to check your blood sugar by finger prick using test strips and a glucose monitor 5 times per day, 3 days per week (Tuesday. Thursday and Saturday) for a 3month period after the birth of your child. You will be required to check your blood sugar in the following manner: in the moming before breakfast (fasting), 1 hour after meals (breakfast, lunch and dinner) and before bed time. You will be required to keep dietary records and breastfeeding records on the days that you check your blood sugar using the forms given to you. You will have to go the clinic to check your weight at 6 weeks and 3 months after the birth of your baby. At the third month after the birth of your child, a small amount (1-teaspoon) of your blood will be taken to measure the amount my sugar in the red blood cells.

Your decision whether or not to participate will not prejudice you or your medical care. If you decide to participate, you are free to withdraw your consent and to discontinue participation at any time without prejudice to you or effect on your medical care.

You understand that the risks of participating on the study, if any, are minimal. You will have to stick your finger with a small needie. It is possible that your inger could get irfected if not done properly. You will be instructed on the proper way to test you blowd glucose to avoid any infections. You understand that the risks of participating will not be different than that experienced in testing blood sugar levels while you were pregnant

This study will be of potential benefit to the medical community and to women who have diabetes during pregnancy. This study will involve approximately 40 women who will participate for 3 months each. This study will provide health care professionals working with diabetes, information on the potential benefts of breastieeding on blood sugar levels in women who have diabetes. You may or may not receive some small benefit by having your blood sugars levels lowered sooner by participating in this study.

WE CANNOT AND DO NOT GUARANTEE OR PROMSE THAT YOU WLL RECEVE ANYBENEFITS FROM THIS STUDY. 
You will be told if any new informatton is leamed which may affect your condition or intuence your wilingness to continue participation in this study.

While participating in this study, you should not take part in any other research project without approval from all of the investigators. This is to protect you from possible injury arising from such things as extra blood drawing, extra $x$-rays, interaction of research drugs, or similar hazards.

Breastfeeding and bottlefeeding are the two appropriate altemative procedures, for nourishing your child. You have voluntarily chosen to use one or the other of these two procedures (but not both) for the entire duration of the 3-month study. You understand that if you chose to change the method you have chosen before the end of the study, you will have to withdraw from the study.

Any data that may be published in scientific joumals will not reveal the identity of the subjects. *Patient information may be provided to Federal and regulatory agencies as required. The Food and Drug Administration, for example, may inspect research records and learn your identity if this study falls within its jurisdiction.

No payment will be provided for participation in this project.

There will be no cost for your participation in this study

The Department of Nutrition and Food Science at San Jose State University is involved in the study through cooperative research and a small grant in aid of research.

At the discretion of the protocol director subjects may be taken out of this study due to unanticipated circumstances.

Some possible reasons for withdrawing a subject from the study.

- fallure to follow instructions

- the investigator decides that continuation could be harmful to you

- you need treatment not allowed in the study

- the study is canceled

- other administrative reasons

If you have any questions, we expect you to ask us. If you have any additional questions later, Dr Clarie Hollenbeck at (408) 924-3106 will be happy to answer them.

All forms of medical diagnosis and treatment - whether routine or experimental - involve some risk of injury. In spite of all precautions, you might deveiop medical complications from participating in this study. If such complications arise, the researchers will assist you in obtaining appropriate medical treatment but this study does not provide financial assistance for additional medical or other costs. Additionally Stanford is not responsible for research and medical care by other institutions or personnel participating in this study. You do not waive any liabilly rights for personal injury by signing this fom. For further information, please call (650) 723-5244 or write the Administrative Panel on Human Subjects in Medical Research, Administrative Panels Office, Stanford University, Stanford, CA 94305-540t. In addition, if you are not satisfied with the manner in which this study is being conducted or if you have any questions concerning your rights as a sudy participant, please contact the Human Subjects Office at the same address and telephone number. 


\section{Human Subiects Blll of Rights}

As a human subject you have the following rights. These rights include but are not Inmited to the subject's right to:

- be infomed of the nature and purpose of the experiment;

- be given an explanation of the procedures to be followed in the medical experiment, and any drug or device to be utilized; - be given a description of any attendant discomforts and risks reasonably to be
expected; - be given an explanation of any benefits to the subject reasonably to be
expected, if applicable;

- be given a disclosure of any appropriate altematives, drugs or devices that might be advantageous to the subject, their relative risks and benefits:

- be informed of the avenues of medical treatment, if any available to the subject atter the experiment if complications should rise; - be given an opportunity to ask questions concerning the experiment or the
procedures involved;

- be instructed that consent to participate in the medical experiment may be withdrawn at any time and the subject may discontinue participation without
prejudice:

- be given a copy of the signed and dated consent form;

- and be given the opportunity to decide to consent or not to consent to a medical experiment without the intervention of any element of force, fraud, deceit duress, coercion or undue influence on the subject's decision.

YOUR SIGNATURE INDICATES THAT YOU HAVE READ AND UNDERSTAND THE ABOVE INFORMATION, THAT YOU HAVE DISCUSSED THIS STUDY WITH THE PERSON OBTAINING CONSENT, THAT YOU HAVE DECIDED TO PARTICIPATE BASED ON THE INFORMATION PROVIDED, AND THAT A COPY OF THIS FORM HAS BEEN GIVEN TO YOU.

Social Security \#; Necessary ONLY when being paid

\section{*Person Obtaining Consent}

lattest that the requirements for informed consent for the medical research project described in this form have been satisfied - that the participant has been provided with the Experimental Subject's Bill of Rights, if appropriate, that I have discussed the research project with the participant and explained to him or her in nontechnical terms all of the information contained in this informed consent form, including any risks and adverse reactions that may reasonably be expected to occur. I further certify that I encouraged the participant to ask questions and that all questions asked were answered.

Approval Date: 719102 Expiration Date: $\quad 7 / 8 / 03$ 


\title{
Appendix $G$
}

\author{
Informed Consent: Spanish
}

\section{CONSENTMIENTO DNEORMADO}

Usted está participando en cualquier otro estudio de investigación? Si No.

Título del protocolo: Los Efectos de Amamantar en los niveles de la Glucosa en la Sangre de Mujeres Latinas con Sobrepeso e Historia de Diabetes Gestacional.

\section{$07 / 16 / 02$}

Le invitan a que participe en un estudio cuyo objetivo es investigar los efectos de amamantar en los niveles de la azucar en la sangre de mujeres que han temido diabetes durante el embarazo. Esperamos apreader hacerca de los efectos del amamantar con los niveles de azucar en la sangre y su con el control de su peso. Le seleccionaron como un participante posible en este estudio porque es usted Latina o Hispana y ha tenido diabetes durante su embarazo.

Su participación en este estudio es enteramente voluntaria. Si usted decide participar, nosotros le pediremos que se mida su aivel de azucar en la sangre utilizando unas tiras de papel y una maquina que sirve para medir la azucar en la sangre. Debera medirse el givel de su azucar 5 veces al dia, 3 dias de la semana (Martes, Iueves y Sabado). Este procedimiento se efectuara durante los tres meses posteriores al parto. El patrón de medición del azucar será el siguiente: Se medira el azucar antes del desayuno (en ayunas), 1 hora despues de cada comida (desayuno, almuerzo y cena) y antes de ir a dormir por la noche. Los especialistas de la investigacion le proveeran unos formularios donde tendra que escribir todos los alimentos que ingiera durante el dia, y además debern anotar las veces que amamanto a mi bebe durante los dias que mida mi azucar. Debera asistir a la clinica a las 6 semanas y 3 meses depues del parto con el objetivo que midan su peso. Al tercer mes despues del parto le tomaran una muestra de sangre para que se mida el nivel de azucar en su sangre.

Su decisión de participar o no, no le perjudicará a nsted o a su atención médica. Si usted decide participar, usted está libre de retirar su consentimiento y continuar la participación en cualquier morsento sin prejuicio alguno para usted o sobre su asistencia médica.

Como procedimiento rutinario para medir el nivel de azucar en su sangre tendra que picarse uno de sus dedos con una aguja. Debera seguir las recomendaciones y cuidados higienicos para evitar infecciones. En resumen, los resgos son los mismos de cuando usted tenia diabetes duranie su embarazo y media se azucar en la sangre.

Este estudio traera multiples beneficios para la salud publica y para las mujeres que hayan tenido diabetes durante el embarazo. Un aproximado de 40 mujeres va ba participar en este estudio y este estudio va ha durar un aproximado de 3 meses, desde el parto de su bebe hasta que su bebe tenga 3 meses. Este estudio proporcionara hemamientas a los profesionales que trabajan con diabetes, ayudandoles a un mejor entendimiento del control del azucar en la sangre cuando se trate de una mujer que amamante y a la vez que haya tenido historia de diabetes durante el embarazo. Usted recibira o no un beneficio de que la ayude a bajar los niveles de azucar en la sangre por participar en el esmaio.

\section{NO PODEMOS Y NO GARANTIZAMOS NI PROMETEMOS OUE USTED RECIBIRÁ ALGÚN BENEFICIO DE ESTE ESTUDIO.}

La dirán si se descubre alguna información nueva la cual puede afectar su condición o influir su buena voluntad de continuar su participación en este esnudio.

Mientras participa en este estudio, usted no debe participar en ninguin otro proyecto de investigación sin ia aprobación de todos los investigadores. Esto debe protegerle contra posible lesión que se pueda 
presentar en cosas tales como la extracción adicional de sangre, rayos $X$ adicionales, Ia interacción de las drogas de la investigación o peligros similares.

Tenga conocimiento que hay otros metodos de alimentar a mi bebe a parte de dar pecho como el de dar biberon. Si usted decide dar biberon tambien puede participar en este estudio. Tambien sepa que hay ortos alimentos solidos a parte de la leche para el bebe, pero no se recomiendan hasta que el bebe tenga por lo menos 4 meses de edad.

Cualquier dato que se pueda publicar en diarios ciemtificos no revelará la identidad de los sujetos. La información del pariente se puede proporcionar a las agencias federales y reguladoras según lo requerido. La Administración Federal de Alimentos y Drogas, por ejemplo, pueden examinar expedientes de la investigación y conocer su identidad si este estadio está deztro de su jurisdicción.

No va ha recibir dinero por participar en el estudio.

E] Departamento de nutricion de la Universidad de Sari Jose esta cooperando con un peqeño abonamiento para el estudio.

A discreción del director del protocolo los swetes pueden ser retirados de ente estudilin debido a circunstancias inesperadas.

Algunas razomes posibles de retirar an sujeto del estudio. (Note to investigator: you may use these reasons andior add some of your own.

- no sigue las instrucciones

- el investigador decide que la continuación podria serle dañina

usted necesita tratamiento no permitido en el estudio

el estudio está cancelado

- otras razones administrativas

Si usted tiene cualquier pregunta, esperamos que usted nos las haga. Si usted tiene cualquier pregunta adicional más adelante, el doctor Clarie Hollenbeck al (408) 924-3106 gustosamente le responderá.

Todas las pruebas de diagnóstico médico y tratamiento - ya sean rutinarias ó experimental presentan cierto Jiesgo. A pesar de las precauciones, usted podria desarrollar complicaciones médicas Aebicu a su participación en este estudio. Si surgieran tales complicaciones, los investigacores le asistirian para obtener el tratamiento médico, pero el estudio no proporciona ayuda financiera para tratamiento médico adicional u otros gastos. (@Además, Stanford no es responsable para la investigación y el cuidado médico por otras instituciones o del personal que participan en este estudio.) Al firmar este formulario, usted no renuncia a ninguno de sus derechos de responsabilidad eivil en caso de lesiones personales. Para información más detallada, por favor llame al (650) 723. 5244 o escriba al Administrative Panel on Human Subjects in Medical Research, Administrative Panel Office, Stanford University, Stanford, CA 94305-5401. Además, si usted no está sacisfecha(o) con la manera en que se dirige el estudio o si tiene preguntas con respecto a sus derechos como participante en el estudio, por favor comuniquese con el Administrative Ponel on Human Subjects in Medical Research a la misma dirección y teléfono. 
Las personas que participan en experimentos médicos tienen los siguientes derechos que incluyen, pero no se limitan a:

- que se les informe sobre la naturaleza y el propósito del experimento,

- que se les expliqquen los procedimientos a realizarse en el experimento y de cualquier medicina o instrumentos que se utilizarán,

- que se les describa cualquier malestar y los riesgos razonables,

- que se les explique, si ese es el caso, cualquier beneficio razonable que los participantes pudieran esperar,

- que se les informe de cualquier alternativa apropiada, las medicinas o aparatos que pudieran beneficias al sujeto, sus riesgos relativos y beneficios,

- que se les informe de las vias de trataniento médico, si las hay, disponibles al sujeto después del experimento en caso de surgir complicaciones,

- que se les dé la oportunidad de hacer.preguntas concemientes al experimento o a los procedimientos usados,

- que se les haga saber que el consentimiento para participar en el experimento médico puede ser retirado en cualquier momento y que el sujeto puede terminar su participación sin perjuicio,

- que se les dé una copia del consentimiento firmado y con fecha,

- y que se les dé la oportunidad de decidir si dan consentimiento o no al experimento sin la intervención de ningun elemento de fuerza, fraude, engaño, coacción, coerción o influencia indebida en la decisión del sujeto.

SU FIRMA INDICA OUE USTED HA LEIDO Y TENTENDDDO LA INFORMACIÓN ANTERIOR, QUE HA HABLADO SOBRE ESTE ESTUDIO CON EL INVESTIGADOR PRTNCIPAL Y SU PERSONAL, QUE HA DECIDIDO PARTICIPAR BASÁNDOSE EN LA INFORMACION PROPORCIONADA Y QUE LE HA SIDO ENTREGADA UNA COPIA DE ESTE FORMULARIO.

Número de seguro social; (SS\# Necessan ONLY when being paid)

Person Obtaining Consemt

I atsest that the requirements for informed consent for the medical research project described in this form hove been satisfied - that the participant has been provided with the Experimental Subject's Bill of Rights, if appropriate, that I hove discussed the research project with the participant and explained to him os her in nontechnical terms all of the information contained in this informed consent form, including any risks and adverse reactions that may reasonably be expected to occur. I further certify. that I encouraged the participant to ask questions and that all questions asked were answered. 
Appendix $\mathrm{H}$

Flyer in English

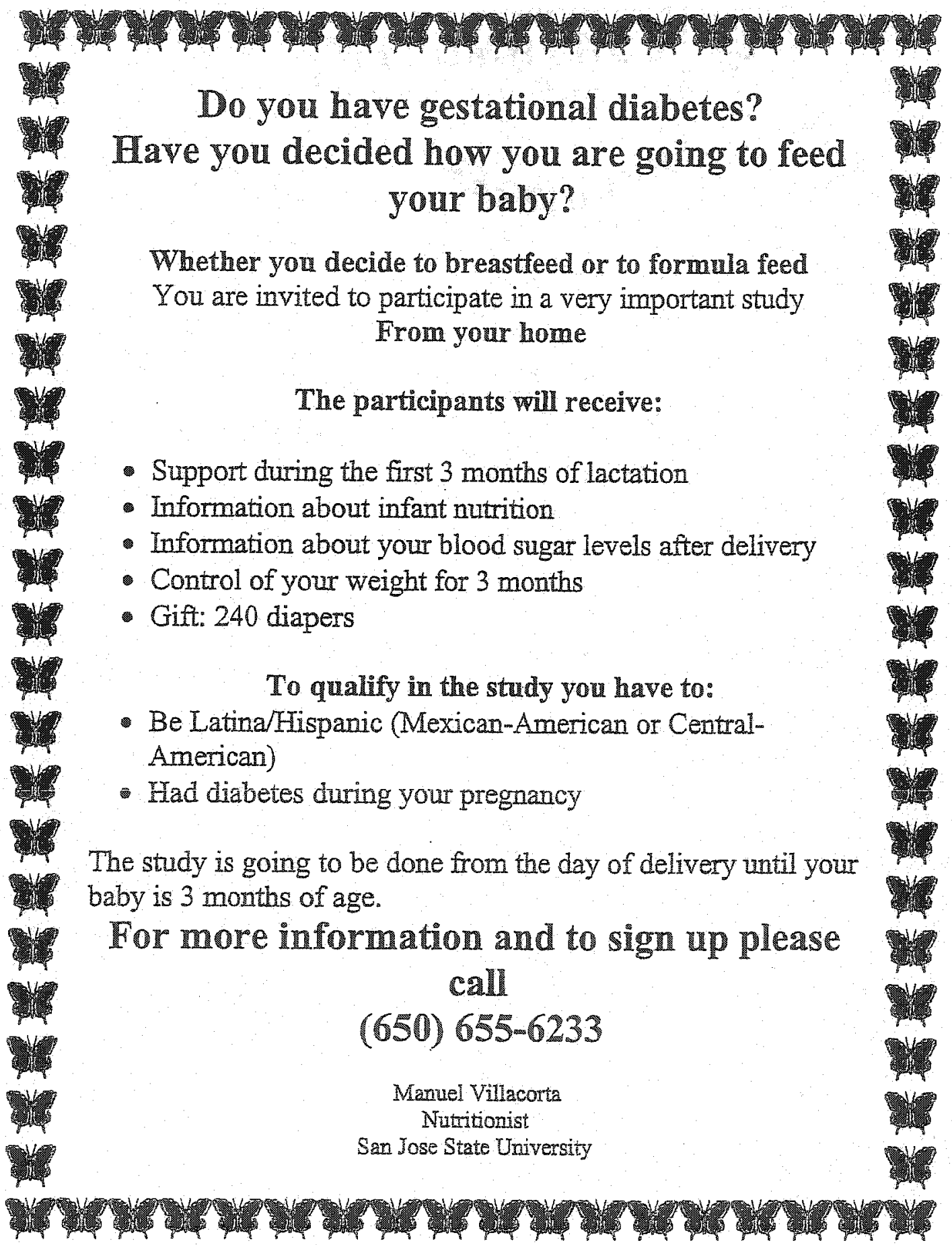


Appendix I

Flyer in Spanish

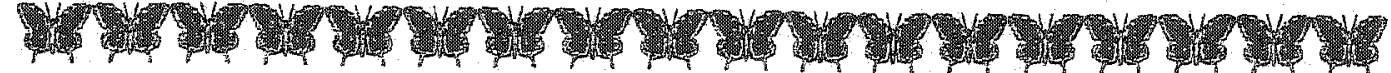

跑

16)

\section{Tiene usted diabetes durante su embarazo?}

\section{Ya ha pensado como alimentar a su bebe?}

Asi decida dar pecho o formula.

Ud. esta invitada para participar en un importantisimo estudio desde su casa

Los participantes reciviran:

- Apoyo durante los 3 primeros meses de la lactancia

- Informacion sobre alimentacion del bebe

- Informacion sobre sus niveles de azucar despues del embarazo

- Control de su peso por 3 meses

- Regalo: 240 pañales

Para calificar en el estudio tiene que:

- Ser Latina (Mexicana o Centro Americana)

- Haber tenido Diabetes Durante el embarazo

El estudio se va ha efectuar desde el parto hasta que su bebe tenga 3 meses de edad.

Para mas informacion y/o participar en el estudio por favor de llamar (650) $655-6233$

Manuel Villacorta Nutritionist San Jose State University 


\section{Appendix J}

Data Collection Tools: English

Name:

\begin{tabular}{|c|c|c|c|}
\hline $\begin{array}{c}\text { Time to measure my } \\
\text { blood sugar }\end{array}$ & Tuesdiny & Thursday & Saturday \\
\hline Fasting & & & \\
\hline 1 hour after breakfast & & & \\
\hline 1 hour after lunch & & & \\
\hline 1 hour after dinner & & & \\
\hline \\
Before bed time
\end{tabular}

WEEK 2

\begin{tabular}{|c|c|c|c|}
\hline $\begin{array}{c}\text { Time to measure my } \\
\text { blood sugar }\end{array}$ & Tuesday & Thursday & Saturday \\
\hline Fasting & & & \\
\hline 1 hour after breakfast & & & \\
\hline 1 hour after lunch & & & \\
\hline 1 hour after dinner & & & \\
\hline \\
Before bed time
\end{tabular}




\section{Breastfeeding Record}
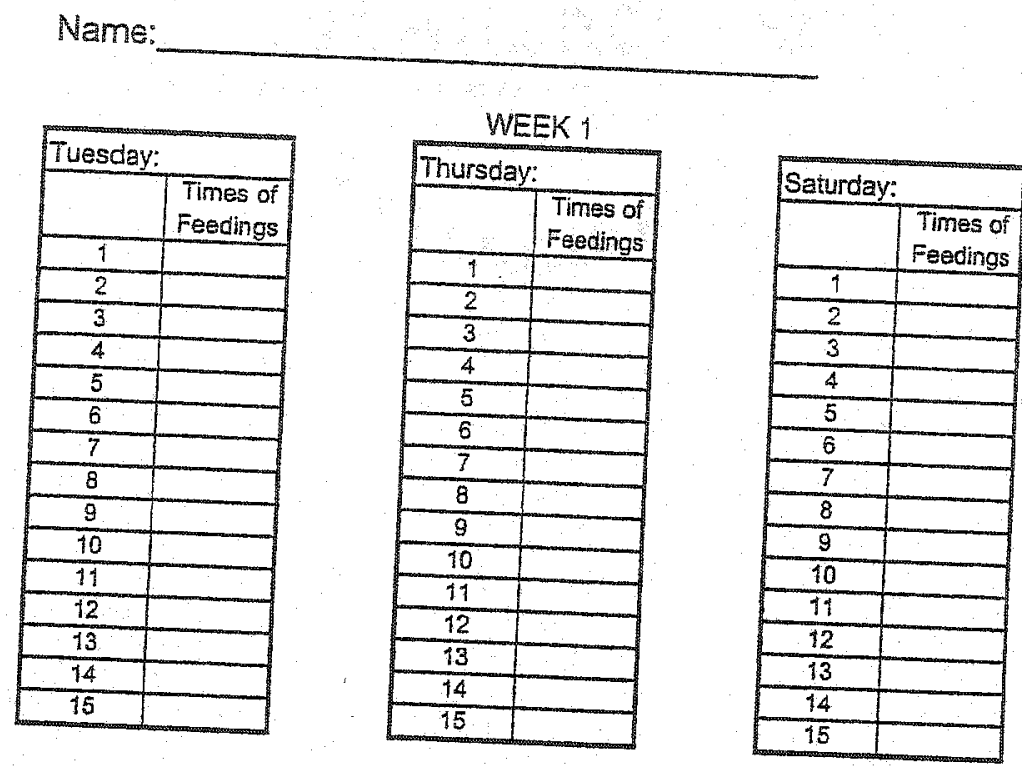

\begin{tabular}{|c|c|}
\hline \multicolumn{2}{|c|}{} \\
\hline 1 & $\begin{array}{l}\text { Times of } \\
\text { Feedings }\end{array}$ \\
\hline 2 & \\
\hline 3 & \\
\hline 4 & \\
\hline 5 & \\
\hline 6 & \\
\hline 7 & \\
\hline 8 & \\
\hline 9 & \\
\hline 10 & \\
\hline 11 & \\
\hline 12 & \\
\hline 13 & \\
\hline 14 & \\
\hline 15 & \\
\hline
\end{tabular}

WEEK 2

\begin{tabular}{|c|c|}
\hline & $\begin{array}{c}\text { Thmes of } \\
\text { Feedings }\end{array}$ \\
\hline 1 & \\
\hline 2 & \\
\hline 3 & \\
\hline 4 & \\
\hline 5 & \\
\hline 6 & \\
\hline 7 & \\
\hline 8 & \\
\hline 9 & \\
\hline 10 & \\
\hline 11 & \\
\hline 12 & \\
\hline 13 & \\
\hline 14 & \\
\hline 15 & \\
\hline
\end{tabular}

\begin{tabular}{|c|c|}
\hline Saturday: \\
\hline & $\begin{array}{c}\text { Times of } \\
\text { Feedings }\end{array}$ \\
\hline 1 & \\
\hline 2 & \\
\hline 3 & \\
\hline 4 & \\
\hline 5 & \\
\hline 6 & \\
\hline 7 & \\
\hline 8 & \\
\hline 9 & \\
\hline 10 & \\
\hline 11 & \\
\hline 12 & \\
\hline 13 & \\
\hline 14 & \\
\hline 15 & \\
\hline
\end{tabular}


Name:

WEEK 1

Tuesday:

Thursday:

Saturday:

\begin{tabular}{|c|c|c|}
\hline & Breakfast & \\
\hline Breakfast & & \\
\hline Snack & Snack & Snack \\
\hline Lunch & & \\
\hline Snack & Lunch & Lunch \\
& & \\
\hline & & \\
\hline Dinner & Snack & \\
\hline & & \\
\hline & Dinner & \\
\hline
\end{tabular}


Appendix $\mathrm{K}$

Data Collection Tools: Spanish

Nombre:

\begin{tabular}{|c|c|c|c|}
\hline $\begin{array}{c}\text { Tiempo de medir el } \\
\text { azucar ez mi sangre }\end{array}$ & Martes & Jueves & Sabado \\
\hline $\begin{array}{c}\text { Ayunas } \\
\text { I hora despues de la comida } \\
\text { (mañana) }\end{array}$ & & & \\
\hline $\begin{array}{c}\text { I hora despues de la comida } \\
\text { (tarde) }\end{array}$ & & & \\
\hline $\begin{array}{c}\text { I hora despues de la comida } \\
\text { (noche) }\end{array}$ & & & \\
\hline & & & \\
\hline
\end{tabular}

\begin{tabular}{|c|c|c|c|}
\hline $\begin{array}{l}\text { Tiempo de medir el } \\
\text { azucar en mi sangre }\end{array}$ & Martes & Jueves & Sabado \\
\hline Aymas & & & \\
\hline $\begin{array}{l}1 \text { hora despues de la comida } \\
\text { (mañana) }\end{array}$ & & & \\
\hline $\begin{array}{l}\text { 1 hora despues de la comida } \\
\text { (tarde) }\end{array}$ & & & \\
\hline $\begin{array}{l}1 \text { bora despues de la comida } \\
\text { (noche) }\end{array}$ & & & \\
\hline Antes de ir a dormir & & & \\
\hline
\end{tabular}




\section{Diario de Lactancia}

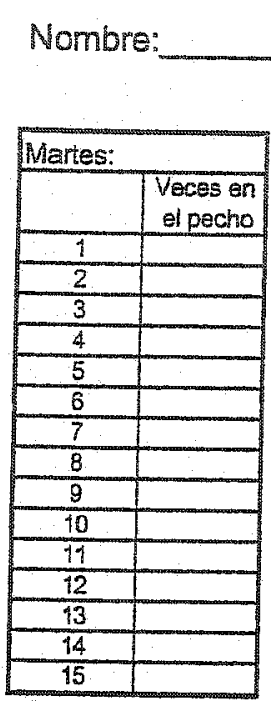

SEMANA 1
\begin{tabular}{|c|c|}
\hline Jueves: \\
\hline & $\begin{array}{l}\text { Veces en } \\
\text { el pecho }\end{array}$ \\
\hline 1 & \\
\hline 2 & \\
\hline 3 & \\
\hline 4 & \\
\hline 5 & \\
\hline 6 & \\
\hline 7 & \\
\hline 8 & \\
\hline 9 & \\
\hline 10 & \\
\hline 11 & \\
\hline 12 & \\
\hline 13 & \\
\hline 14 & \\
\hline 15 & \\
\hline
\end{tabular}

\begin{tabular}{|l|l|}
\hline Sabado: \\
\hline & $\begin{array}{l}\text { Veces en } \\
\text { el pecho }\end{array}$ \\
\hline 1 & \\
\hline 2 & \\
\hline 3 & \\
\hline 4 & \\
\hline 5 & \\
\hline 6 & \\
\hline 7 & \\
\hline 8 & \\
\hline 9 & \\
\hline 10 & \\
\hline 11 & \\
\hline 12 & \\
\hline 13 & \\
\hline 14 & \\
\hline 15 & \\
\hline
\end{tabular}

\begin{tabular}{|c|c|}
\hline Martes: \\
\hline & $\begin{array}{l}\text { Veces en } \\
\text { el pecho }\end{array}$ \\
\hline 1 & \\
\hline 2 & \\
\hline 3 & \\
\hline 4 & \\
\hline 5 & \\
\hline 6 & \\
\hline 7 & \\
\hline 8 & \\
\hline 9 & \\
\hline 10 & \\
\hline 11 & \\
\hline 12 & \\
\hline 13 & \\
\hline 14 & \\
\hline 15 & \\
\hline
\end{tabular}

\section{SEMANA 2}

\begin{tabular}{|c|c|}
\hline Jueves: & \\
\hline & $\begin{array}{l}\text { Veces en } \\
\text { ol pecho }\end{array}$ \\
\hline 1 & \\
\hline 2 & \\
\hline 3 & \\
\hline 4 & \\
\hline 5 & \\
\hline 6 & \\
\hline 7 & \\
\hline 8 & \\
\hline 9 & \\
\hline 10 & \\
\hline 11 & \\
\hline 12 & \\
\hline 13 & \\
\hline 14 & \\
\hline 15 & \\
\hline
\end{tabular}

\begin{tabular}{|c|c|}
\hline Sabado: & \\
\hline & $\begin{array}{l}\text { veces en } \\
\text { el pecho }\end{array}$ \\
\hline 1 & \\
\hline 2 & \\
\hline 3 & \\
\hline 4 & \\
\hline 5 & \\
\hline 6 & \\
\hline 7 & \\
\hline 8 & \\
\hline 9 & \\
\hline 10 & \\
\hline 11 & \\
\hline 12 & \\
\hline 13 & \\
\hline 14 & \\
\hline 15 & \\
\hline
\end{tabular}


Nombre:

SEMANA 1

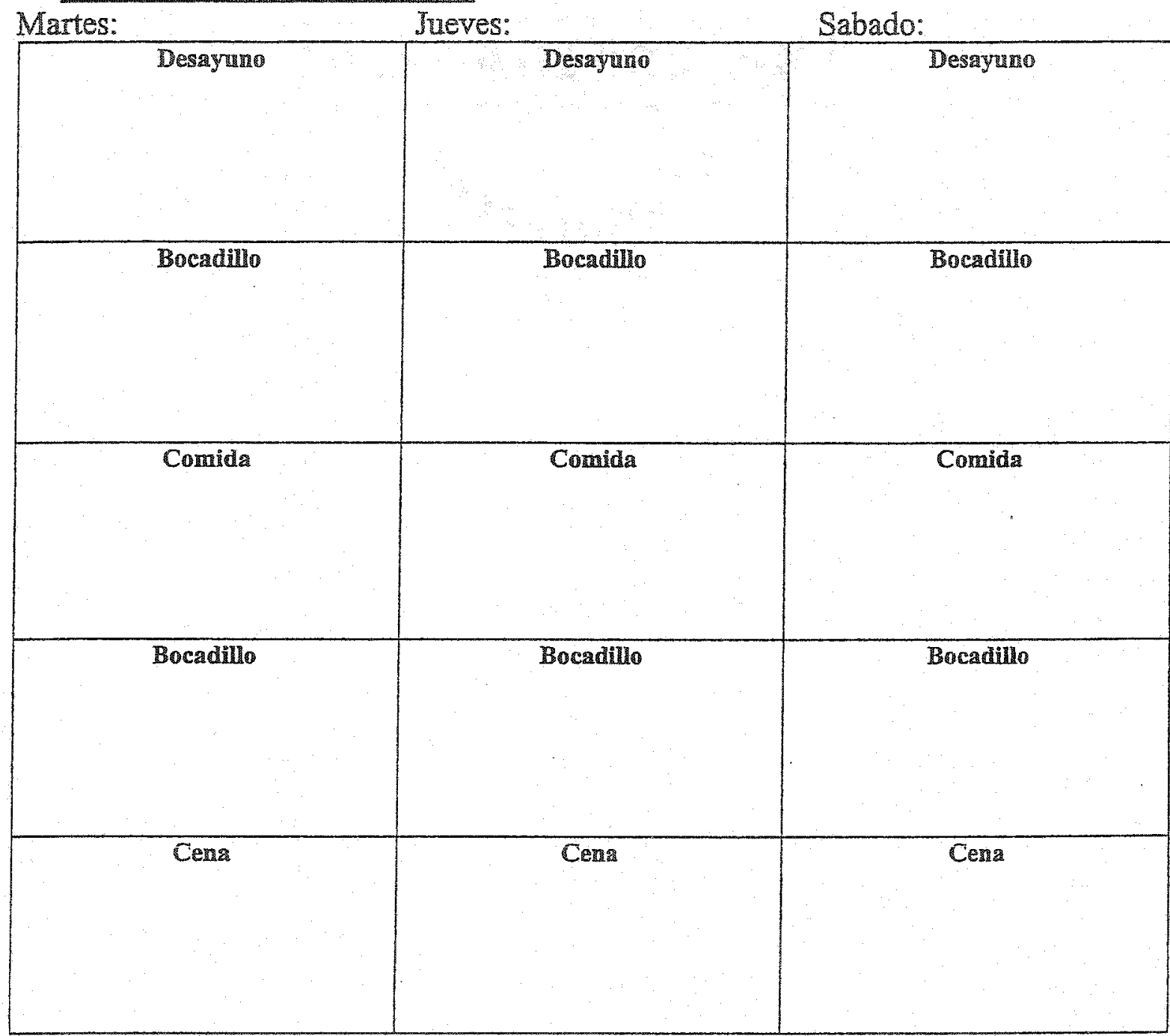

